$8-17-2013$

\title{
Teacher Retention in the Low-Income Diverse Community of Immokalee, Florida
}

Ashley M. Buehler

Cedarville University

Follow this and additional works at: http://digitalcommons.cedarville.edu/education_theses

Part of the Bilingual, Multilingual, and Multicultural Education Commons

\section{Recommended Citation}

Buehler, Ashley M., "Teacher Retention in the Low-Income Diverse Community of Immokalee, Florida" (2013). Master of Education Research Theses. 63.

http://digitalcommons.cedarville.edu/education_theses/63 
TEACHER RETENTION IN THE LOW-INCOME DIVERSE COMMUNITY OF

IMMOKALEE, FLORIDA

A thesis submitted in partial fulfillment

of the requirements for the degree of

Master of Education

By

ASHLEY MICHELE BUEHLER

B.A. Middle Childhood Education, Cedarville University, 2007

2013

Cedarville University

School of Education 


\title{
TEACHER RETENTION IN A LOW-INCOME DIVERSE COMMUNITY
}

\author{
Abstract \\ Buehler, Ashley M. M.Ed., School of Education, Cedarville University, 2013. Teacher Retention \\ in the Low-Income Diverse Community of Immokalee, Florida.
}

This qualitative ethnographic study explores the background characteristics and motivations of nine long-standing teachers in the small migrant community of Immokalee, Florida. Each teacher participated in a standard open-ended interview consisting of 55 questions. Common background characteristics exist among the teachers. The teachers are life-long learners, embrace challenges, possess a familiarity with their school context, and interestingly the majority of the teachers pursued another profession before becoming an educator. All the teachers communicated their love for the students and community of Immokalee, however, four dissatisfying factors emerged throughout the interview process these include: insufficient time, the negative perception directed towards Immokalee, standardized testing, and difficulty communicating with parents who have limited education and English language skills. Despite these obstacles, seven themes of endurance seem to contribute to these educators' ability to perseverance as a teacher in Immokalee. These include: the desire to make a difference, working in a supportive school environment, personal faith, establishing a boundary between work and school, keeping bureaucracies on the outskirts of their job, viewing students as individuals and maintaining a positive relationship with parents. Administrators should consider the findings of this study when hiring individuals to fill vacant teaching positions in low-income high diversity settings such as Immokalee. 


\section{TABLE OF CONTENTS}

CHAPTER 1: INTRODUCION

Definition of Terms ......................................................................................... 6

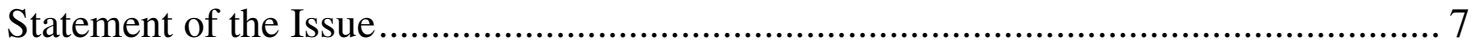

Scope of the Study and Delimitations ................................................................ 9

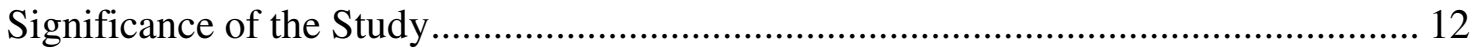

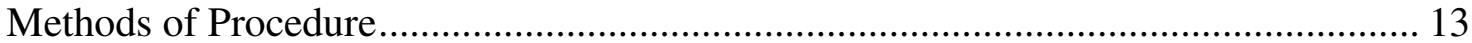

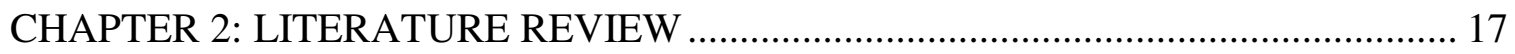

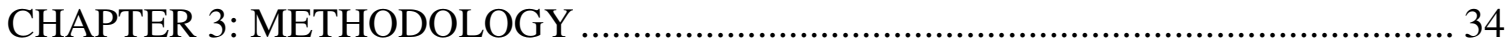

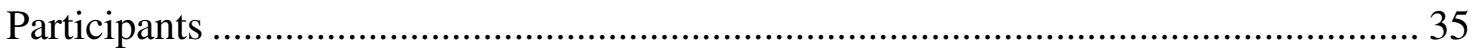

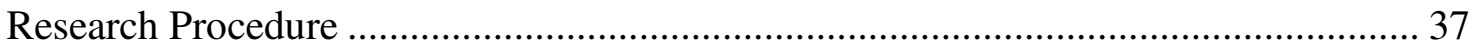

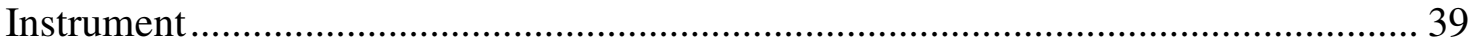

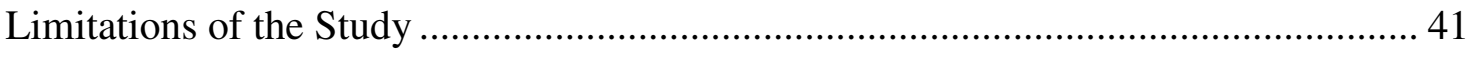

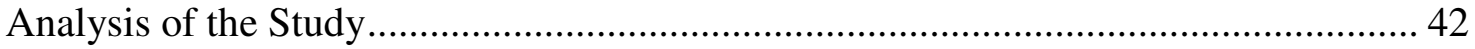

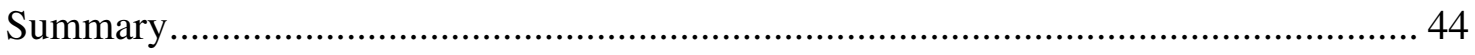

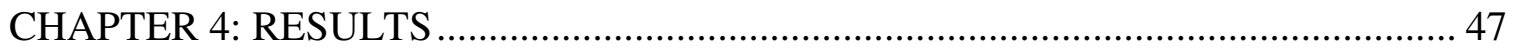

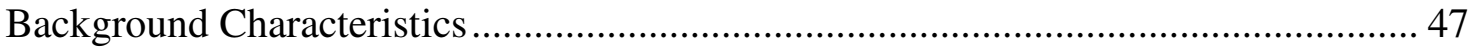

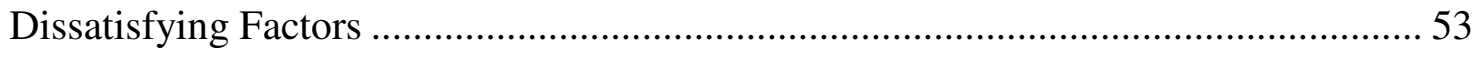

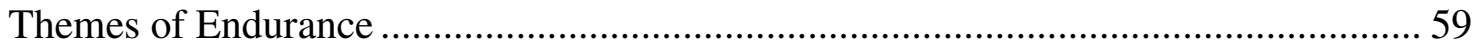

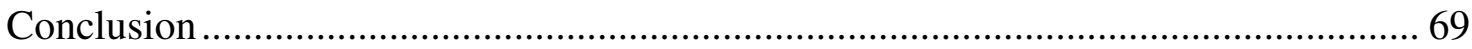




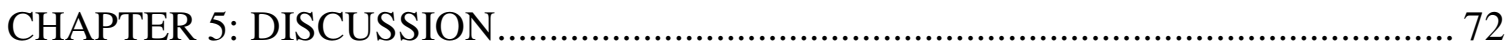

Recommendations Regarding the Hiring of Immokalee Teachers ............................ 76

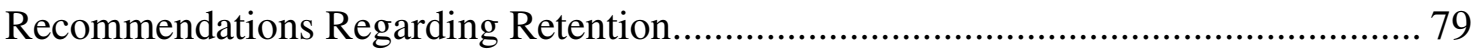

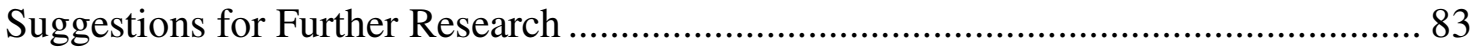

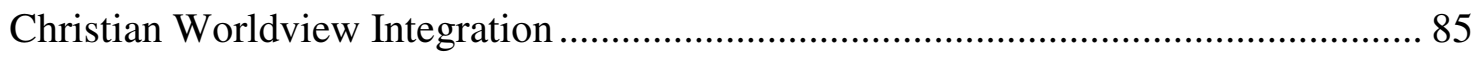

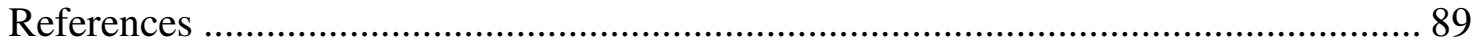

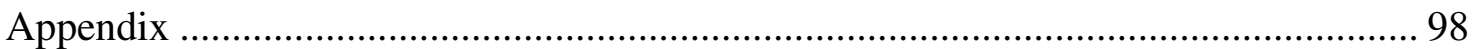




\section{TEACHER RETENTION IN A LOW-INCOME DIVERSE COMMUNITY}

\section{Chapter 1}

\section{Introduction}

The student population in American schools is much more diverse today than in previous generations (Ferguson, 2007). This increase in diversity has had a profound impact on the education of America's youth. Humes, Jones, and Ramirez (2010) reported from information gathered in the 2010 census, that while the non-Hispanic White population remains the largest population group numerically and proportionally, it has grown more slowly than any other racial group. This group decreased from representing $75 \%$ of the population in 2000 to only $73 \%$ of the population in 2010. The African-American population also grew more slowly than most of the other population groups increasing by only $12 \%$. While there have not been large increases in the White and African-American population, all other major racial groups have increased substantially. More than one-half of the population growth in the United States from 2000 to 2010 was due to the growth of the Hispanic population. The Asian population has grown by $43 \%$, increasing from $4 \%$ of the total U.S. population in 2000 to $5 \%$ in 2010 . The population of the Native Hawaiian and Other Pacific Islander group alone has increased by more than onethird, while the American Indian and Alaska Native group increased to 18\%. The number of people that identified themselves as "Some Other Race" increased from 15.4 million people in 2000 to 19.1 million in 2014, increasing by about one-quarter. Burney and Beilke (2008) noted that the increase in the diversity of the student population is evident in schools all across the country. This, in addition to new federal mandates, increases the demand for highly qualified teachers that can adequately educate America's diverse youth. (Elfers, Plecki, \& Knapp, 2006).

As schools in the United States have become more diverse, the achievement gap has widened. As Clayton (2011) reports, schools that consist of students of lower socioeconomic 


\section{TEACHER RETENTION IN A LOW-INCOME DIVERSE COMMUNITY}

status (SES) and more diverse populations do not have as high levels of academic achievement. Among Virginia elementary schools, Clayton found that schools with more African-American and Hispanic students had higher levels of poverty while schools with more White students had lower levels of poverty. Additionally Clayton found lower pass rates on state mandated tests in higher-poverty higher-minority schools. In recent years, closing the achievement gap between affluent White students and high-poverty minority students has been emphasized by education policy makers; however, often teachers lack skills to differentiate their instruction to meet the needs of immigrants, English as a second language (ESL) students, and a growing African American and Latino population (Ferguson, 2007). Furthermore, high-poverty high-minority schools are the schools that administrators have the most difficult time recruiting and retaining teachers (Darling-Hammond, 1997). The distribution of teachers in American schools increases the inequality that permeates public schools because low-income and diverse students often receive instruction from inexperienced and ineffective teachers (Darling-Hammond, 2007).

Clayton (2011) found that teachers with credentials such as scoring high on state licensure tests, graduating from a competitive college, and possessing an advanced degree usually teach in schools in which the student population is more advantaged. These schools are composed of mainly White students that do not participate in the free or reduced lunch program and have more educated parents (Clotfelter, Lagg, \& Vigdor, 2006). High-poverty schools tend to hire more inexperienced teachers, teachers who have graduated from less competitive colleges, or teachers that do not possess regular licenses. These schools generally have teachers with the lowest teacher test scores and the lowest percentage of teachers that possess National Board Certification (Clotfelter, Lagg, \& Vigdor, 2010). It is problematic that inexperienced teachers and teachers with less certification often occupy the classrooms of high-poverty high- 


\section{TEACHER RETENTION IN A LOW-INCOME DIVERSE COMMUNITY}

minority schools since teacher effectiveness is one of the most important factors of student success (Darling-Hammond, 2007; Rockoff, 2004). Research shows that experience and certification correlates strongly with a teacher's effectiveness. Clotfelter et al., (2006) found that novice teachers are linked with the lowest student test scores and the most effective teachers have between 13 and 26 years of experience. Additionally Clotfelter et al., (2006) found that students who are taught by an experienced teacher score about one-tenth of a standard deviation higher on math standardized testing and a little less than one-tenth of a standard deviation higher on reading standardized tests. Overall, a student with a weak teacher, as defined by experience and certification, can be expected to perform 0.23 standard deviations lower than they would score if they were taught but a strong teacher (Clotfelter et al., 2010). Burney and Beilke (2008) emphasized that in order for low-income students to achieve the skills needed for their success they need to be educated by long-term teachers who consistently show support and care. Unfortunately, long-term teachers are difficult to find in high-poverty high-minority schools.

A negative correlation exists between the poverty level of a school's population and teacher retention. This correlation between teacher retention and student SES exists in both high poverty urban and suburban schools (Elfers et al., 2006). A negative correlation between teacher mobility and school context also exists among schools that consist of diverse populations.

Schools with a relatively high concentration of African-American students are more likely to experience teacher mobility (Elfers et al., 2006; Goldhaber, Gross, \& Player, 2011). Goldhaber et al. (2011) state that the issue of concern is the fact that many highly effective teachers leave the education field or transfer out of high-poverty schools while ineffective teachers are likely to transfer from school to school. Regardless, both effective and ineffective teachers are more likely to transfer schools when teaching in schools consisting of high numbers of low performing 


\section{TEACHER RETENTION IN A LOW-INCOME DIVERSE COMMUNITY}

or disadvantaged students. These conditions make it difficult for high-poverty, high-minority schools to recruit and retain effective teachers. Elfers et al. (2006) states that instability among the teaching staff of schools may contribute to low academic performance especially in schools consisting of high percentages of students of low SES. High rates of teacher turnover disrupt student learning and the community of the school. Extensive research conclusively points to the fact that high-poverty high-minority schools not only hire teachers with less credentials and experience, but additionally many of these teachers quickly exit their school placement which leaves frequent teacher vacancies in schools where students are already at high risk due to life circumstances.

There are a variety of reasons as to why teachers choose to leave their schools. The nature and stability of an educator's teaching assignment, the colleagues they work with, the geographic location of the school, its proximity to home, as well as personal and family considerations all influence teachers' decisions to leave or remain at a school. Leaders impact the schools' environment which in turn affects teachers' decisions to stay in a school (Elfers et al., 2006). Ingersoll (2001) found that among urban, high-poverty schools teachers leave due to low salaries, poor student behavior and motivation, and little administrative support. DarlingHammond (1997) stated that school districts that have a large population of low-income students often pay teachers lower salaries and provide teachers with fewer materials. Teachers in these schools experience less professional autonomy and often have larger class sizes. Those working in schools of low SES and diverse student populations usually experience poorer working conditions. Elfers et al. (2006) said that state and federal mandates target schools of low SES and diverse student populations. In order to retain teachers in challenging school contexts it is essential that teachers receive resources, support, and incentives. 


\section{TEACHER RETENTION IN A LOW-INCOME DIVERSE COMMUNITY}

Despite the difficulties that teachers face while teaching in challenging school contexts, there are teachers who manage to teach for long periods of time at these schools. Through a variety of studies, there are consistent characteristics found among educators who persevere in difficult school contexts.

Ganchorre and Tomanek (2012) found that prospective secondary science and math teachers, who commit to teaching in districts composed of a large number of low SES students, are aware of educational challenges. They know and understand the difficulties that influence their students. These teachers are also more comfortable around communities of diverse people. They either grew up in a low-income household themselves or encountered situations earlier in life in which they had to interact with diverse populations and people of low income.

Cohen (2009) found common characteristics between two teachers who taught in the same urban school for over 25 years. Both teachers put themselves first. Their classrooms were teacher-centered and they demonstrated a passion for the subject they teach. They had an unusual ability to forget bad experiences and were able to prevent unpleasant work experiences from affecting their personal life. In addition, race was a non-issue for these teachers. The teachers interviewed also shared insightful information regarding their teaching philosophy. Both believed that academics should be valued above all else. They admitted this may require removing students who can't learn or refuse to learn. Both stated that they think teaching should be teacher-centered and that they teach primarily for themselves, not the students. They both enjoy working with students, but they derive satisfaction from the act of teaching.

Haberman (1995) suggests that effective urban educators are persistent and that they themselves are learners. They are able to generate practical applications to education theories. These teachers do not make excuses for their students' learning and believe they are largely 


\section{TEACHER RETENTION IN A LOW-INCOME DIVERSE COMMUNITY}

responsible for their students' learning. Successful urban teachers respect their students but do not see affection as necessary for learning. They recognize that some students and parents may not like them, but that does not prevent them from teaching the student and expecting them to learn. These teachers are able to avoid burnout by recognizing that they must work within bureaucracies and they are able to protect themselves from these bureaucracies. They allow students to make mistakes and are not afraid to admit their shortcomings.

Richardson, Alexander, and Castleberry (2008) found that emotive dissonance and communication symmetry correlated with teachers' intent to leave. Among the two, communication symmetry was the greatest predictor of attrition among teachers and is especially important in low performing, high poverty, and multicultural schools. Bobek (2002) identified teacher resiliency is a distinguishing factor among educators who stay great lengths of time in low-income schools.

\section{Definition of Terms}

Migrant: People on the move with little time to establish community ties; they live in isolation even when they live in high density areas (Prewitt-Diaz, Trotter, \& Rivera 1990).

No Child Left Behind Act of 2001: A law that requires states to set standards for student performance and teacher quality. This law holds schools and teachers accountable for student achievement and establishes schools that are more inclusive and fair (U.S. Department of Education, 2004).

English language learner (ELL): Refers to students who are non-native English speakers. These students perform poorly on assessments that measure English language proficiency (Muyskens, Betts, Lau, \& Marston, 2009). 


\section{TEACHER RETENTION IN A LOW-INCOME DIVERSE COMMUNITY}

Exceptional student education (ESE): Refers to services provided to students with disabilities and those who are gifted (Florida Department of Education, n.d.).

Limited English proficiency (LEP): Refers to students in which English is not their first language. They are not fluent in English and may have difficulty speaking or reading English (U.S. Department of Health \& Human Services, 2009).

Burnout: When job demands exceeds one's mental, emotional, or physical ability to complete the task. Burnout also occurs when job demands exceed the resources provided to complete the task (Demerouti, Nachreiner, \& Schaufeli, 2001).

Adequate yearly progress: No Child Left Behind requires each state to establish rigorous standards and assessments to annually measure the academic achievement of each school and school district in the state. States are required to identify for improvement any Title I school that does not meet the state's standards for adequate yearly progress for two consecutive years (U.S. Department of Education, 2004).

High-stakes testing: Tests that are administered to students that have serious consequences for the school, teachers, and the students. Consequences for high scores on highstakes tests include monetary bonuses and negative consequences including loss of jobs. If persistent low scores occur, the state can come in and take over the school (Callet, 2005).

\section{Statement of the Issue}

No Child Left Behind (NCLB) specifically addresses the need to improve the education of all students. Under NCLB all subgroups of a school must meet Adequate Yearly Progress (AYP) goals. Subgroups include limited English proficiency (LEP) students, special education students, and students who are economically disadvantaged (U.S. Department of Education, 2004). Since teachers greatly influence student achievement there should be great efforts made to attract and 


\section{TEACHER RETENTION IN A LOW-INCOME DIVERSE COMMUNITY}

retain school teachers at low SES schools. Urban schools have been the focus of previous research studies on this topic; however, few studies investigate teacher retention in high poverty, multicultural, rural schools.

Immokalee, Florida is a migrant, rural community located in Collier County. There are five elementary schools, one middle school, and one high school. These schools are high poverty, multicultural schools. In addition, they serve many migrant students. Migrant students present schools with unique challenges. According to Velasquez (1994) the migrant population in the United States has supported the economy of the United States for decades, but many people know little about migrant workers' lives. The most uneducated group of people in the United States are migrant workers. They move around the country to find work and once a crop harvests the family moves to another area of the country for work. On average, migrant workers work for $\$ 4.80$ an hour or they are paid 40 cents per bushel and do not receive benefits (Velasquez, 1994). Earning money is difficult due to poor weather, sickness, traveling, and waiting for crops to harvest. Only $50.7 \%$ of migrant teenagers graduate from high school (BOCES Geneseo Migrant Center, n.d.). Prewitt-Diaz et al. (1990) explained that one reason for this is because migrant parents consider boys to be adults around age 15 or 16 and girls when they are able to have children. As a result, many children drop out of school to assist their parents in the fields. Often, parents give their children a choice of going to school or working in the fields. Migrant parents are usually supportive of schools and value education; however, it is difficult for them to support their child's education due to their inability to speak English and their lack of understanding of the American school system. Also, migrant workers and their families often have poor physical health (BOCES Geneseo Migrant Center, n.d.). 


\section{TEACHER RETENTION IN A LOW-INCOME DIVERSE COMMUNITY}

Teaching in a school with a large population of migrant students is challenging. The challenges the students and teachers face in this context varies significantly with diverse, urban schools. Determining the reasons for a teacher's choice to stay within the above context will expand current research and contribute valuable knowledge to school districts and others involved in the process of hiring teachers.

\section{Scope of the Study and Delimitations}

This study will collect data from public school teachers who have served in Immokalee, Florida for more than ten years. Each teacher will be interviewed and asked questions concerning their motivations for staying in their current school. Demographic data relating to their background, such as where they grew up, the type of school they attended as a child, and their educational history etc. will be collected to determine if there are any persistent themes.

This study will focus on teachers that teach at a school in Immokalee, Florida.

Immokalee is located 45 miles northeast of downtown Naples and lies five miles away from the border of Lee and Hendry County. It is primarily an agricultural town and is one of the largest farmworker communities located in the State of Florida (Thissen, 2002, p. xxiii). According to the U.S. Census Bureau (2010) in 2010 the population of Immokalee totaled 24,154 people. Immokalee's population is diverse. In 2010 the population of Immokalee consisted of 4.1\% White non-Hispanic, $18.9 \%$ African-American, 1\% American Indian and Alaskan Native, 0.2\% Asian, 0.2\% Native Hawaiian and other Pacific Islander, and 75.6\% Hispanic and of Latin origin. About 46.7\% of those livings in Immokalee between 2006 and 2010 were foreign born. For those above the age of five, $84 \%$ of the population spoke a language other than English at home. 


\section{TEACHER RETENTION IN A LOW-INCOME DIVERSE COMMUNITY}

From 2006 to 2010, the median household income in Immokalee was 23,897 dollars. About $41.2 \%$ of the population were below the poverty level and the per capita money income for the last 12 months of 2010 was 9,948 dollars (U.S. Census Bureau, 2010). The town also has difficulty receiving federal funding because Naples, a retirement and vacation community, makes Collier County one of the wealthiest counties in the United States (Thissen, 2002, p. xxviii). The education level of those living in Immokalee is quite low. From 2006 to 2010, only $29.7 \%$ of those over the age of 25 were high school graduates and only $3.9 \%$ of the population had a bachelor's degree or higher (U.S. Census Bureau, 2010).

It is interesting to note that Immokalee schools are part of the Collier County public school system and therefore, the schools receive funding from Naples tax dollars. Unlike many other schools in low-income areas, Immokalee schools do not lack resources. In fact, Collier County schools are a leading school district in technology. The Collier County school district is a large district that, in 2012, consists of forty-eight schools. The district allows teachers to transfer from one school to another within the district. Immokalee teachers receive the same compensation as those in Naples, with the exception of two schools. These schools underwent restructuring and, as a result, these teachers work longer hours and receive higher compensation. Many teachers commute to Immokalee from the surrounding communities. The district gives all teachers in Immokalee a gas stipend. This stipend, however, does not fully cover the cost of gas. With the exception of the two schools that receive higher compensation due to longer work hours, there is no financial incentive to teach in Immokalee rather than Naples.

Conducting this research in Immokalee contributes a unique perspective on teacher longevity. The student population of Immokalee is composed of high-poverty, diverse, and transient students. Teachers in these schools face a variety of challenges and it is important to 


\section{TEACHER RETENTION IN A LOW-INCOME DIVERSE COMMUNITY}

determine what characteristics constitute a teacher who is able to persevere and continue in this challenging environment. Previous research studies found that teacher retention is often based on the geographic location of the school and its proximity to home (Elfers et al., 2006). Many of the teachers working in Immokalee commute over thirty minutes to work. These teachers are also eligible to transfer to other schools in the district when positions are available. Schools in Immokalee have a significantly more difficult time recruiting and retaining teachers than those in Naples even though they are a part of the same school district. Ingersoll (2001) states that often schools, within the same district, vary significantly in their ability to recruit and retain teachers. This finding appears to be true for Collier County Schools.

There are several delimitations present in this study. Only public school teachers will be invited to participate in the study. There are several reasons for this. First, charter and private schools are not expected to comply in the same way with the federal mandates to which the public schools must adhere. Federal mandates influence daily school routines and could affect teachers' intent to stay. Second, Perie and Baker (2007) found that teachers in public, charter, and private schools experience different levels of job satisfaction. Teachers in private schools generally are more satisfied. Between charter schools and public schools, charter school teachers reported higher levels of satisfaction due to increased autonomy, but they also had higher levels of attrition (Renzulli, Parrott, \& Beattie, 2011). The higher levels of attrition in charter schools may be partly due to the fact that charter school teaching positions are less secure because charter schools are not unionized like public schools (Stuit \& Smith, 2012). Third, student SES varies between charter, public, and private schools. Usually parents have to pay to send their child to a private school. Those parents who cannot afford to send their child to a private school have to enroll them in either a charter or public school causing an unequal distribution of student 


\section{TEACHER RETENTION IN A LOW-INCOME DIVERSE COMMUNITY}

SES between the three types of schools. Furthermore, the racial composition of students in private, charter, and public schools varies significantly. For example, Bifulco and Ladd (2007) found that charter schools enroll a disproportionately high percentage of African-American students compared to public schools. Sohoni and Saporito (2009) also found that higher percentages of White children attend schools of choice than non-White children. Lastly, teacher compensation is often different between private, public, and charter schools and most definitely affects teachers' decisions to stay or leave their school. Including teachers from all three school types would result in multiple extraneous variables and decrease the validity of the study.

There are two schools in Immokalee in which the teachers receive higher compensation due to school restructuring. This raise in compensation was implemented in recent years. Since this study focuses primarily on the intrinsic reasons teachers remain in their school only teachers who completed at least ten years of experience in one of these schools prior to the extended day and increase in salary will be included. The different level of compensation could create a variable that would affect the results.

Music, physical education, and art teachers were not included in this study since their jobs vary significantly with other subject areas. The day-to-day job responsibilities of these teachers is different and their curriculum is not directly related to standardized testing. Since these classes are focused on the arts the expectations required of students are much different from other classes. This creates a different classroom environment for both the student and the teacher.

\section{Significance of the Study}

The achievement gap between schools is of great concern. Schools consisting of large numbers of students of low SES generally do not perform as well on high-stakes tests. There has 


\section{TEACHER RETENTION IN A LOW-INCOME DIVERSE COMMUNITY}

been much emphasis placed on closing this achievement gap. Hiring qualified teachers in highpoverty high-minority schools is of high priority.

Determining factors that encourage longevity of teachers in low-income schools will contribute valuable knowledge because it will give principals insight as to which types of candidates are more likely to remain in challenging school contexts. Increasing longevity among teachers will improve student achievement in these schools.

The results of this study in combination with previous studies conducted in urban schools, will give principals knowledge regarding characteristics of teachers that are persistent and able to persevere through the challenges that come with teaching a diverse population of students, many of which are migrant. Not only will this study help principals know what types of applicants to hire, but it will also give them information as to how to better implement policies and practices so that teachers feel well supported and desire to remain in their school. Knowing the reasons why teachers serve long lengths of time in Immokalee schools will prove to be beneficial.

\section{Methods of Procedure}

\section{Research Questions}

1. What motivates teachers to continue working in an Immokalee school for long periods of time when others find this work difficult and do not remain for long lengths of time?

2. What causes these teachers to persevere and succeed at their work?

3. What background characteristics are common among long standing teachers in Immokalee? 


\section{TEACHER RETENTION IN A LOW-INCOME DIVERSE COMMUNITY}

This research study is an inductive qualitative research study in which the researcher sought to determine the underlying reasons why a teacher chooses to continue to work in the high-poverty, high-minority Immokalee schools. Much of the methodology of this study is derived from a study by Cohen (2009) in which interviews were conducted with two inner-city teachers who remained for over twenty-five years in the same school. The present study expands upon Cohen's research by determining teachers' motivations for remaining in a high-poverty high-minority rural school located in the migrant community of Immokalee. This study is an ethnographic study since the researcher will ascertain descriptive characteristics regarding the beliefs, values, norms, and attitudes of teachers who have worked in a public school in Immokalee for more than ten years (Johnson \& Christensen, 2008). The participants of this study were selected using purposive sampling since the researcher interviewed teachers who meet the criteria of teaching in an Immokalee school for at least ten years (Johnson \& Christensen, 2008). The researcher contacted the school principals in Immokalee and asked for a list of teachers who have taught in their school for at least ten years. The researcher then contacted individual teachers from these lists and asked for participation. Those who agreed to take part participated in a standardized open-ended interview in which they were asked openended questions in a specific order (Johnson \& Christensen, 2008). The researcher asked the teachers questions regarding their background as well as questions to determine their motivations and incentives for continuing to teach in Immokalee. The participants received the interview questions before the interview in order to allow the participants ample time to process the questions. This increased the internal validity of the study by reducing the number of participants that answered questions quickly and without thought due to perceived pressure to answer the question promptly. To triangulate the data interviews were conducted with multiple 


\section{TEACHER RETENTION IN A LOW-INCOME DIVERSE COMMUNITY}

teachers in a variety of classroom settings (Johnson \& Christensen, 2008). All the interviews were recorded and transcribed. The research was conducted through a grounded theory approach using the constant comparative method (Glaser \& Strauss, 1967). In order to implement the constant comparative method the researcher read though all of the interviews and used open coding to chunk parts of the transcript into smaller significant segments (Johnson \& Christensen, 2008; Leech \& Onwuegbuzie, 2007). Transcripts were coded via axial coding methodology to compare new phrases and comments with previous comments (Johnson \& Christensen, 2008). Categories were developed based upon common expressions and ideas found among multiple participants and similar pieces of information were given the same code (Leech \& Onwuegbuzie, 2007). After coding the data, selective coding was used to look for similar themes and commonalities regarding the background of the teachers and central motivations for remaining in Immokalee (Johnson \& Christensen, 2008; Leech \& Onwuegbuzie, 2007). The constant comparative method can be executed deductively, inductively, or abductively (Leech \& Onwuegbuzie, 2007). This study was inductive since the codes emerged from the data as it is analyzed (Leech \& Onwuegbuzie, 2007). Follow-up interviews were continued until theoretical saturation occurred in which no new data emerged from the interviews (Johnson \& Christensen, 2008).

In interviews subjective words and comments can easily be misinterpreted or misunderstood. It is vital that the final analysis accurately reflects participants' comments; therefore interpretive validity measures of participant feedback were used (Johnson \& Christensen, 2008). Participant feedback clarifies and corrects miscommunication. Participants had the opportunity to review a summary of the final analysis and results of the study. Participants were given the opportunity to clarify or expound upon parts of the analysis that they 


\section{TEACHER RETENTION IN A LOW-INCOME DIVERSE COMMUNITY}

felt do not accurately represent their thoughts and intentions. This process helped correct for any miscommunication between the researcher and the interview participants and resulted in a more accurate and valid study. 


\section{TEACHER RETENTION IN A LOW-INCOME DIVERSE COMMUNITY}

\section{Chapter 2}

\section{Literature Review}

Education reform is not exclusively an American endeavor. Reform agendas are occurring in various countries around the world due to globalization, technological advances, and competition (Organisation for Economic Co-operation and Development [OECD], 2011).

Teaching is profoundly different than in previous generations as governments have become more involved in education. This control has led to changes in the curriculum, the assessment of students, and ultimately the role of the teacher (Codd, 2005). In many countries teacher accountability and student achievement, measured by high-stakes testing, has become paramount (Day \& Gu, 2009). Despite international efforts to improve education, many advanced countries are experiencing shortages particularly when looking for specialist teachers and teachers to serve in disadvantaged schools (OECD, 2011).

In the United States, the level of teacher attrition varies greatly between districts and even between schools within the same district (Day \& Gu, 2009). Attrition has detrimental effects on American schools and should be of concern. Barnes, Crowe, and Schaefer (2007) found that the financial consequences of teacher turnover are great, often costing school districts thousands of dollars each time a teacher leaves (Barnes et al., 2007). Attrition also has organizational consequences. Donaldson and Johnson (2011) stated that high levels of attrition make it difficult for schools to keep track of students' progress and other information from year to year. Stability within a school allows schools to establish positive relationships with parents and others in the community (Donaldson \& Johnson, 2011). Perhaps the greatest concern is the influence teacher attrition has on student performance. Guin (2004) stated that a constant change in the instructional staff of a school causes discontinuity within the curriculum and interferes 


\section{TEACHER RETENTION IN A LOW-INCOME DIVERSE COMMUNITY}

with students' learning. Students perform better when under the instruction of a teacher who is committed to their job (Day \& Gu, 2009).

Greater education, licensure, and certification requirements have prevented many from entering the profession (Cockburn, 2000). This has limited the applicant pool and made it more

difficult for some schools to recruit qualified teachers. For example, Monk (2007) explained that small rural schools often need teachers to teach multiple subjects, but it is difficult for these schools to find teachers who possess the necessary credentials since the federal government requires teachers to be highly qualified in every subject they teach. Cockburn (2000) said that only those with higher academic credentials are able to train for teaching. Those with these credentials are also those who qualify for more profitable professions (Omenn, Strunk, \& Robinson, 2006). On average, teachers' salaries are $20 \%$ lower than the salaries of other professionals who have similar education and training credentials (Darling-Hammond, 2003). As a result, many teachers leave teaching because they can earn sufficiently higher wages elsewhere (Omenn, Strunk, \& Robinson, 2006).

Numerous research studies have explored the influence of salary and other pecuniary benefits on the recruitment, retention, and satisfaction of teachers. Cockburn (2000) found that salary impacts recruitment and that some people avoid the profession due to the fact that the salary simply does not meet their financial needs. Darling-Hammond (2003) found that teacher compensation does influence teachers' decision to remain in their school. Studies have reached different conclusions about the relationship between salary and teacher satisfaction. Dinham (1992) found that salary is a neutral factor in regards to teacher satisfaction, but Perie and Baker (1997) concluded that salary and benefits have a little influence on teacher satisfaction and that teachers who receive additional income through additional school activities tend to have greater 


\section{TEACHER RETENTION IN A LOW-INCOME DIVERSE COMMUNITY}

job satisfaction. Inman and Marlow (2004) identified salary as the only external source of retention among beginning teachers. Results of a study conducted by Stinebrickner (1998) suggested that increasing teachers' salaries may limit teacher attrition more than improving working conditions, yet McKinney, Berry, Dickerson, and Campbell-Whately (2007) found through interviews that financial incentives did not motivate teachers to continue working in their high-poverty school settings. Although financial incentives are a common recruitment strategy for high-poverty schools, McKinney et al. suggested that it is unlikely that financial incentives alone will solve the recruitment and retention problems that greatly affect disadvantaged schools. OECD (2011) pointed out that countries that have been successful at making teaching an appealing profession did not do so solely by raising teacher pay, but also by improving the status of teaching, treating teachers as professionals, and involving them in the reform process.

Demographics seem to play a role in teacher retention and attrition. According to Xin and MacMillan (1999) generally, female teachers show more job satisfaction than male teachers. A study by McKinney et al. (2007) revealed that teachers who continued to teach in urban high poverty schools were females between the ages of 32 and 49. Stinebrickner (1998) pointed out that marriage and fertility factors often determine how long teachers choose to continue teaching. The research varies in regards to the relationship between teachers' age, experience, and satisfaction level. Perie and Baker (1997) observed that younger teachers and those with less experience tend to have higher levels of job satisfaction than older more experienced teachers. Xin and MacMillan (1999) also found this to be true. Omenn Strunk and Robinson (2006) came to the conclusion that more experienced teachers are less likely to leave their chosen profession due to their investment in their school district, but teachers with zero to four years of experience 


\section{TEACHER RETENTION IN A LOW-INCOME DIVERSE COMMUNITY}

were more likely to exit the teaching profession. According to McKinney et al. (2007) long serving teachers in urban high-poverty schools had six to twenty-seven years of experience. The literature suggests that attrition rates are higher at the very beginning of a teacher's career and towards the end of their career when they are nearing retirement. The higher levels of attrition among beginning teachers is not surprising since it is a widely known fact that beginning teachers experience high levels of stress due to lesson planning and learning classroom management techniques. The higher attrition rates among veterans may be due to the difficulty they have adapting to education reform. Day and Gu (2009) explained that veteran teachers find it difficult to adjust to the constant changes in education policy and pedagogy due to their long held attitudes and practices.

Teacher satisfaction levels vary depending on the location, size, and type of school. Omenn Strunk and Robinson (2006) said less attrition exists in large schools perhaps because larger schools have more support staff to perform administrative tasks that would be the responsibility of teachers in smaller schools. Perie and Baker (1997) found that teachers who teach in suburbs, small towns, and rural areas have higher satisfaction levels than those in cities. Perie and Baker also identified teachers in private elementary schools as the most satisfied. Additionally, in a study conducted by Renzulli et al. (2011) charter school teachers reported higher levels of satisfaction than public school teachers. Renzulli et al. suggested that the disparity may be because charter school teachers generally are given more autonomy. Although teachers in charter schools reported higher levels of satisfaction, attrition is greater. Renzulli et al. identified the absence of unions as a possible reason for this phenomenon.

In regards to certificates and subject areas, Omenn Strunk and Robinson (2006) found through a study that teachers who possessed a probationary certificate were more likely to quit 


\section{TEACHER RETENTION IN A LOW-INCOME DIVERSE COMMUNITY}

than those who possessed a regular certificate. Special education teachers are more likely to leave the profession than general education teachers (Hughes \& Manuel, 2006). A study conducted by Hughes and Manuel (2006) found that foreign language teachers were more likely to quit than teachers who taught other subjects such as English, social studies, and vocational education classes. Hughes and Manuel revealed that many people choose to teach because they love their subject area and that it should be of concern when teachers are teaching out of their certification area or the subject they prefer to teach. Teach for America (TFA), an organization focused on minimizing the achievement gap, recruits accomplished college graduates, often from highly prestigious universities, to teach in low-income schools for two years (Donaldson \& Johnson, 2011). Donaldson and Johnson (2011) found that teaching assignments affected the retention of TFA teachers. Those who were given more difficult assignments, such as teaching multiple grades and subjects, were more likely to quit or transfer to another school. Also TFA teachers teaching a subject in which they lacked adequate training and preparation were more likely to leave.

Perie and Baker (1997) stated that when teachers have high levels of satisfaction, fewer turnovers occur and instructional quality improves. They suggest that emphasis should be placed on increasing the level of satisfaction among teachers to improve the instruction and education of American students. Intrinsic factors are primarily associated with teachers' satisfaction (Dinham \& Scott, 2000). Several studies revealed that teachers who enjoy their job intended on being a teacher for a long time period prior to beginning their teacher education training (Cockburn, 2000; Dinham \& Scott, 2000). Donaldson and Johnson (2011) found this to be true among TFA teachers. Those who had long term intentions to teach left primarily for family reasons, whereas those who planned on teaching for a short period of time left for other job opportunities and 


\section{TEACHER RETENTION IN A LOW-INCOME DIVERSE COMMUNITY}

because they were displeased with their working conditions. Those teachers who joined TFA with the intention of teaching long term were also more likely to stay in their original, more challenging, school placement.

Certain intrinsic personality and character traits are found among teachers who make education their long-term career choice. Bobek (2002) found resiliency to be an essential trait especially among teachers teaching in challenging school contexts. Another trait of persevering teachers is that they embrace challenges. Cockburn (2000) found that challenges actually increased job satisfaction for a number of teachers. Some teachers initiated challenges by seeking a teaching job with a more difficult student population, grade level, or position. Some added additional responsibilities. Byrne (1994) identified self-esteem as a critical mediator variable in a teacher's ability to cope with negative extrinsic factors.

Intrinsic rewards such as the academic and personal growth of students motivate people to become teachers. Dinham and Scott (2000) found that personal and professional growth were important reasons stated for entering the profession. Numerous studies support this conclusion. First, Hughes and Manuel (2006) found that the majority of educators decided to teach for intrinsic reasons such as a desire to work with young people and make a difference in students' lives. The motivation to make a difference in students' lives encourages the retention of teachers. A study by Cockburn (2000) found that working with students was the prominent reason elementary teachers remained in their jobs. Furthermore, Stanford (2001) found urban teachers' desire to have a positive influence on their students' personal and academic growth motivated them to continue teaching for great lengths of time. Hughes and Manuel (2006) stated that the strong desire to help and influence young people is short lived for some teachers because dissatisfying extrinsic factors can be enough to persuade some teachers to quit. 


\section{TEACHER RETENTION IN A LOW-INCOME DIVERSE COMMUNITY}

Education reform and changes in pedagogy can be a source of teacher dissatisfaction (Moriarty, Edmonds, Blatchford, \& Martin, 2001). According to Moriarty et al. (2001) teachers of young children in England experienced higher levels of stress and dissatisfaction when they had to employ policies and procedures that they felt were ineffective and different from what they were taught and understood to be best practice. Teachers, specifically those with more experience, stated that they had difficulty completing the additional work required due to the changes, and some communicated that these changes negatively impacted their classroom teaching. Day and Gu (2009) stated that teachers in all countries need to be well-supported in order to survive the constant demand of government reform.

Dinham (1992) acknowledged that society's criticism of teachers and the education system serve as a cause of dissatisfaction and that teaching is viewed more negatively now than it was in the past. The public often discusses the ease of the profession (Dinham, 1992). For example, holidays are a common criticism posed by the public and some have suggested that teacher holidays are a reason many become teachers, but Cockburn (2000) found that teachers' holidays do not in and of themselves attract teachers to the profession. Cockburn explained that holidays may influence the retention of teachers. Cockburn also found that the negative perception of teachers in society impacts recruitment and teachers consider the public's attitude towards the teaching profession when making the decision to become a teacher. There is no data to show how many people do not consider teaching as a career due to its low salary and status among the community (Cockburn, 2000).

Lack of community support influences the retention of teachers, especially beginning teachers (Cockburn, 2000). Inman and Marlow (2004) explained that beginning teachers often set unrealistic expectations in order to receive commendation from the community. Failure to 


\section{TEACHER RETENTION IN A LOW-INCOME DIVERSE COMMUNITY}

meet these expectations and a feeling of inadequacy causes them to exit the profession.

Conversely, Inman and Marlow suggested that positive support from the community profits beginning teachers and leads to increased retention among novices. Dinham (1992) interviewed Australian teachers who resigned from their positions. A weak relationship with the community existed in the schools in which they were employed. Communication with parents and the community was rare and generally transpired when negative incidents occurred, however, when positive interaction with parents did take place it increased teacher satisfaction. Findings by Perie and Baker (1997) support the idea that parental support increases satisfaction for teachers.

Since society continues to place more demands on teachers, now more than ever, it is imperative that teachers receive support and encouragement from administrators and supervisors (Dinham \& Scott, 2000). Litrell and Billingseley (1994) found that teachers who received support from their principals typically had higher levels of satisfaction and were more likely to remain in their school than those who did not. They were also less likely to have health problems than teachers who received little support from their principal. A study conducted in Australia by Dinham (1992) concluded that teachers and school personnel resigned from their positions due to poor interaction with administrators and those in school leadership. Administrative support is especially vital to a veteran teacher's instructional effectiveness. Day and $\mathrm{Gu}(2009)$ found that veteran teachers who receive support from their administrators are more likely to remain committed to their profession regardless of impeding health problems and other negative factors that affect their lives. Day and Gu suggest that in order for veteran teachers to remain committed to the changing teaching profession, administrators must sympathize with and support these teachers through reform. New teachers, like veterans, need support (Day \& Gu, 2009). Inman and Marlow (2004) emphasized the need for administrators to 


\section{TEACHER RETENTION IN A LOW-INCOME DIVERSE COMMUNITY}

create opportunities for new teachers to share their ideas with colleagues. Inman and Marlow emphasize the benefit beginning teachers receive from interacting with principals who support their ideas. Ma and MacMillan (1999) found that teachers' positive view of their administration actually reduced the low levels of satisfaction typically held by more experienced teachers and struggling new teachers. Additionally, autonomy influences teachers' satisfaction (Dinham \& Scott, 2000). Dinham (1992) found that involving teachers in the decision making process increased their self-esteem and created a sense of personal accomplishment Furthermore, Dinham found that leaving teachers out of this process added to job stress and burnout. It is essential that principals provide a supportive environment instead of an environment that promotes competition (Littrell \& Billingsley, 1994).

Support from administrators and the community improve the retention of teachers. Collegial support is important as well. For many teachers positive relationships and friendships with those at school influence how much they enjoy their job (Cockburn, 2000). On the contrary, Guin (2004) stated that lack of collaboration among teachers and low levels of trust are characteristics of schools with high teacher attrition. Beginning teachers especially need the support of their peers. Mentors are beneficial to beginning teachers and provide a positive working environment (Gehrke \& McCoy, 2007; Inman \& Marlow, 2004). By providing lesson plan and curriculum ideas, teaching feedback, and encouragement mentors can increase beginning teachers' self-esteem and motivate them to be committed to their school (Inman \& Marlow, 2004). In a study of beginning special education teachers, Gehrke and McCoy (2007), found that among beginning special education teachers those who remained in their positions for long lengths of time had mentors, were given professional development opportunities, and described their school environments as positive and welcoming. Johnson (2011) suggested that 


\section{TEACHER RETENTION IN A LOW-INCOME DIVERSE COMMUNITY}

effective induction programs may be one way to prevent the migration of teachers in urban schools. Stanford (2001) completed a study of persevering elementary teachers who taught in difficult urban schools located in Washington D.C. The teachers interviewed mentioned that the friendships at school and support they received from their colleagues were what they most liked about their school. Interestingly, Stanford found another common source of support among these teachers. Many of them relied on their church communities and personal faith. Several of the teachers interviewed discussed their involvement in church activities and it was clear that they integrated their faith into their daily work activities. Some mentioned that they went to God in prayer when they needed encouragement and renewal.

Discipline problems are another extrinsic source of dissatisfaction and influence teacher retention. Results of research by Dinham (1992) found that both primary and secondary teachers, and teachers across the entire experience spectrum, reported an increase in student discipline problems. Friedman (1995) studied discipline from the perspective of the students. Student observations revealed that teacher stress increased when students demonstrated disrespect towards their teacher or peers and when students were inattentive. Of the two, the highest contributor of burnout was students' display of disrespect towards others. Likewise Byrne (1994) conducted a study and found that classroom climate affects teacher burnout. The study revealed that teachers become emotionally exhausted and more negative when the climate of their classroom worsens. According to Perie and Baker (1997) among secondary teachers those who did not feel threats from students displayed higher levels of satisfaction.

Among teachers in England, New Zealand, and Australia workload correlated most strongly with teacher satisfaction (Dinham \& Scott, 2000). In a study conducted by Dinham (1992) teachers explained that in addition to accountability and performance measures imposed 


\section{TEACHER RETENTION IN A LOW-INCOME DIVERSE COMMUNITY}

by the government, the curriculum has expanded to include social issues that previously were not the responsibility of the school. Teachers shared the difficulty they were having teaching everything in the curriculum in addition to completing the bureaucratic tasks that take time away from classroom teaching. Even teachers with years of experience noted the increasing difficulty of teaching. Novices, in particular, displayed higher levels of stress since classroom management is generally more difficult for them, the workload is greater, and much of that work is completed after school hours. The pressure from society in addition to the emphasis placed on student achievement has decreased teacher satisfaction and increased teachers' workload (Dinham, 1992).

The recruitment and retention problem is much greater in "challenging school contexts." Retention rates vary greatly between school contexts. Omenn Strunk and Robinson (2006) said that teachers are more likely to leave schools with high-poverty levels and schools with large racial minority populations. Guin (2004) found that teachers who teach in schools where there are fewer students that receive free or reduced lunches are usually more satisfied, additionally, his study revealed that among elementary teachers, those who were most satisfied received more benefits and taught in smaller schools composed of fewer racial minority students and students in poverty. A smaller disparity existed between the least and most satisfied secondary teachers, however, findings were similar. Younger teachers with less experience who taught in schools with fewer minority students and students in poverty had higher levels of satisfaction.

Donaldson and Johnson (2011) found that many TFA teachers transferred out of their original school placement. The study found that $43.6 \%$ of the teachers continued to teach in their original school beyond their contract, however, after three years about one half of TFA teachers left their original school. After four years only $14.8 \%$ of the teachers were still teaching in their original 


\section{TEACHER RETENTION IN A LOW-INCOME DIVERSE COMMUNITY}

school. This data further supports the fact that low-income schools and schools with high minority populations have a very difficult time retaining teachers. The priority of Teach for America is to minimize the achievement gap; however, even a great number of TFA teachers transfer out of low-income schools. Schools with the greatest need to hire teachers usually have the smallest applicant pool (Guin, 2004).

There are a variety of explanations for the greater level of attrition in high-poverty and high racial minority schools. First, working conditions are often poor in the neediest schools. This also is a factor in teacher retention and attrition. Donaldson and Johnson (2011) found that working conditions were a significant factor in TFA teachers' decision to change schools. Sixteen percent of TFA teachers attributed their decision to leave to poor administrative leadership and 14\% left due to "lack of philosophical alignment." Administrative leadership, school philosophy, discipline, and even their teaching assignment were contributors to their decision to leave their low-income school and teach somewhere else. Stanford (2001) found through teacher interviews that persevering teachers in urban schools identified class size, sufficient materials, and parental support as ideal teaching conditions. Teachers listed overcrowded classrooms, irresponsible administrators, and lack of supplies as some of the worst scenarios in teaching. Stanford suggested that hiring highly educated teachers alone is not going to solve the retention problem in challenging schools; administrators must provide a pleasant working environment in which teachers are well-supported and choose to stay because they feel they are able to thrive.

Second, Omenn Strunk and Robinson (2006) suggested that the attrition in disadvantaged schools may be due to their unfamiliarity with the environment because poor working conditions most likely are not the sole cause of attrition. Teachers' lack of comfort may contribute to their 


\section{TEACHER RETENTION IN A LOW-INCOME DIVERSE COMMUNITY}

choice to leave. Similarly, Boyd, Lankford, Loeb, and Wyckoff (2003) found that prospective teachers often searched for teaching positions close to their home in areas that are comparable to where they grew up. Dinham (1992) acknowledged that it is often difficult for those who grew up in middle-class society to teach in unfamiliar school contexts consisting of low-income and minority students. Dinham suggested that those from secure backgrounds have a difficult time relating to and providing support for students who deal with challenges such as violence, divorce, homelessness, and poverty. Often new graduates begin teaching in unfamiliar school environments that are not the right match for them; therefore, it is vital that teacher education programs adequately prepare teacher candidates by providing teaching experience in a variety of school contexts (Inman and Marlow, 2004).

Thirdly, racial mismatch influences teacher satisfaction (Fairchild et al., 2012; Renzulli et al., 2011). Renzulli et al. (2011) found that teachers had higher levels of satisfaction when teaching in schools in which the majority of the students matched their racial identity. This was particularly true among White teachers. White teachers had higher levels of satisfaction when they taught in a school composed mostly of White students and lower levels of satisfaction when they taught in a school composed mainly of other racial groups. Likewise, Fairchild et al. (2012) concluded that when at least $70 \%$ of the student population shared the same race as the teacher, the teacher's job satisfaction increased.

The present study is focused on the retention of teachers in Immokalee, Florida. Those who teach in Immokalee face tremendous challenges. Many of the variables mentioned previously that are known to decrease teacher satisfaction and retention are characteristics of Immokalee's schools. First, the schools in Immokalee consist of high-poverty and high-minority populations. Thissen (2002) explained the diverseness of Immokalee. The community is 


\section{TEACHER RETENTION IN A LOW-INCOME DIVERSE COMMUNITY}

composed of three main ethnic groups: Mexicans, Haitians, and Guatemalans. The Mexicans came to Immokalee in the 1970 s to find work and escape poverty. The Haitians came in the 1980s to escape not only poverty but also an oppressive and corrupt government. They came from extreme poverty as Haiti is the poorest country in the western Hemisphere primarily due to poor soil. In the mid-1980s the Guatemalans came to Immokalee. The majority of them are Mayan Indians many of whom faced persecution during Guatemala's "Dirty War." This was a thirty-six year war between the government and the indigenous people. The Mayan Indians faced great persecution including being killed, tortured, and forced to leave their homes. All three of these ethnic groups came to Immokalee to escape the extremely difficult circumstances in their home country and to find work.

Research shows that it is difficult for teachers to teach in an unfamiliar context (Boyd et al., 2005; Day \& Gu, 2009; Dinham, 1992; Omen Strunk \& Robinson, 2006). Most people living in Naples and the surrounding community are unable to relate to the difficult backgrounds many of the people of Immokalee have faced. Carlene Thissen volunteers in Immokalee and in her book she discusses the "culture shock" that she experienced coming back into Naples from Immokalee for one of the first times:

Afterwards, I drove home and experienced culture shock for the first time, going from Immokalee to Naples. It was still early in the evening, and about 8:30, and I was to meet some friends in downtown Naples at an expensive restaurant on Fifth Avenue South. I stared at my closet and could not decide what to wear, because nothing seemed normal. When I arrived at the restaurant, my friends were dressed as usual, with beautiful clothes, perfect hair, and perfect make-up. I always enjoy their company and always like the 


\section{TEACHER RETENTION IN A LOW-INCOME DIVERSE COMMUNITY}

lights, the crowds, and the activity downtown, but somehow this night I was not able to make the transition. I could not stop thinking about Immokalee. (Thissen, 2002, p. 5) Teachers who choose to commute into Immokalee each day most likely sense some level of unfamiliarity with their surroundings. Their unfamiliarity with the environment increases the likelihood of their exit.

Racial mismatch is another extrinsic factor that impacts teacher retention (Fairchild et al., 2012; Renzulli et al., 2011). As stated earlier, Mexicans, Haitians, and Guatemalans are the three main ethnic groups in Immokalee. Any White teachers who teach in Immokalee experience racial mismatch.

The public schools in Immokalee are Title I schools. Research shows that low performing schools have a harder time recruiting and retaining teachers (Day, 2009; Falch \& Rønning, 2007). Titles I schools face additional governmental regulations and requirements. The requirements minimize teacher autonomy, a factor that leads to dissatisfaction (Dinham \& Scott, 2000). The pressure to bring the students up to the standard imposed by the government and society increases teacher stress and can lead to burnout (Dinham, 1992).

Many students in Immokalee are below grade level since they have moved to the United States from other countries, such as Haiti, whose education system differs from the United States. For many students English is their second language and some students do not speak any English. Communicating with parents is challenging since often teachers must communicate through a translator. Additionally, students who come from very poor areas of Haiti often lack computer skills which also can inhibit their learning. Working with tutors, translators, and special education teachers requires extra planning time. Extra time is spent planning lessons in 


\section{TEACHER RETENTION IN A LOW-INCOME DIVERSE COMMUNITY}

order to effectively differentiate instruction to meet the needs of disadvantaged students. All of these things increase teacher workload, an indicator of attrition (Dinham \& Scott, 2000).

Teachers are more likely to stay in a school if there is parental support (Perie \& Baker, 1997). In Immokalee, a great number of parents are unable to be involved in their child's education for a variety of reasons. First, many parents work long hours in the fields and are unavailable. Their work schedule makes it difficult for them to come to the school to meet with teachers and they get home too late to help their children with their school work. Additionally, many of the children's parents don't speak English and have very little education themselves. For these reasons it is difficult for them to help their children with their school work.

A lack of support from friends, family, home, and the community may be felt by some teachers in Immokalee and could influence their decision to remain. Many people in Naples will not even go to Immokalee because they are fearful (Thissen, 2002, p. xii). Others' negative perception and misunderstandings about Immokalee could cause them to look down on a teacher's decision to work in such a setting. Additionally, many Americans hold negative views towards immigration laws and do not support the education of immigrants.

While high attrition rates exist in high-poverty, high-minority schools, the literature suggests that it is the extrinsic factors that often accompany these demographic factors that actually impact teachers' decision to leave. Research suggests that administrative practices including support impact teacher retention more than school demographics (Darling-Hammond, 2003; Murnane \& Olsen, 1989). Therefore, improving working conditions should be of high priority in high-needs schools (Darling-Hammond, 2003). Even though the attrition rates are discouraging, the research should prompt education practitioners into action. Since the problems 


\section{TEACHER RETENTION IN A LOW-INCOME DIVERSE COMMUNITY}

contributing to attrition are primarily extrinsic in nature, they can be improved if teachers, administrators, and policy makers work together to make the necessary changes.

A pleasant and encouraging working environment in which teachers are well-supported along with teachers who possess intrinsic qualities such as a strong desire to work with children, an eagerness to embrace challenges, and resiliency are needed in Immokalee. The purpose of this study is to identify the factors that have encouraged long standing teachers to remain in the unique and diverse community of Immokalee. Darling-Hammond (2003) emphasized that more than student demographics, the most important variable in determining the academic growth of students is having well-prepared and committed teachers in the classroom. 


\section{TEACHER RETENTION IN A LOW-INCOME DIVERSE COMMUNITY}

\section{Chapter 3}

\section{Methodology}

It is difficult to retain teachers in low-income high-diversity schools. The Immokalee schools of Collier County, Florida serve primarily a low-income diverse population consisting of many migrant students. Many teachers in Immokalee only remain in Immokalee for a few years and then transfer to more affluent schools. This qualitative study explores the perceptions, experiences, and motivations of long-standing teachers in Immokalee. The study is ethnographic in nature because it is seeking to discover common background characteristics and motivations of the target population of teachers who remain teaching in Immokalee for at least ten years. The following three research questions are addressed:

1. What motivates teachers to continue working in an Immokalee school for long periods of time when others find this work difficult and do not remain for long lengths of time?

2. What causes these teachers to persevere and succeed at their work?

3. What background characteristics are common among long standing teachers in Immokalee?

Johnson and Christensen (2008) define an ethnographic study as a study in which the researcher writes about the people and describes the culture of a group of people including their attitudes, values, norms, practices, patterns of interaction, and perspectives. This study is an ethnographic study in that the intent is to describe the culture of long-standing teachers in Immokalee. Insight was gained from members within the group of Immokalee teachers. The interview questions address the teachers' attitudes regarding learning and schooling. Some questions address their values and norms such as their teaching philosophy and methodology. The study addresses the patterns of interaction among the teachers including their interaction with others, administrators, parents, and the community. Additionally, the researcher tried to 


\section{TEACHER RETENTION IN A LOW-INCOME DIVERSE COMMUNITY}

gain an understanding on teaching in Immokalee from the teachers' perspectives such as how others view their decision to teach in Immokalee.

In previous studies researchers have examined qualities of long-standing teachers in diverse and low-income school contexts, but this study is unique in that it explores the qualities of long-standing teachers within the migrant community of Immokalee. The goal of the study is to identify common characteristics of the population of teachers who have had long tenure in Immokalee so that administrators can make more informed decisions when hiring personnel to work in the Immokalee schools.

\section{Participants}

The intent of this study is to examine the target population of long standing teachers in Immokalee. The researcher used nonprobability sampling techniques including criterion and snowball sampling to select participants. Cohen (2009) states that it is rare for teachers to remain in an urban school for more than ten years, especially committed teachers with high academic credentials. Even though the schools in Immokalee are not urban schools, they contain many attributes of urban schools. Urban schools are often composed of a diverse population of students, many of whom are from low-income families. These low-income, high-diversity schools perform lower on state mandated tests (Clayton, 2011). The percentage of ESE students and students with limited or no English skills is greater, and often children in urban schools face a variety of challenges such as divorce, homelessness, poverty etc. Many urban schools are Title I schools (Clayton, 2011) and Title I schools create unique challenges for teachers including minimized autonomy and additional governmental regulations (Dinham \& Scott, 2000). All of these characteristics are representative of the Immokalee schools. Immokalee is a diverse community in which many are below the poverty level and do speak a language other than English at home (U.S. Census Bureau, 2010). All the schools in Immokalee are Title I schools 


\section{TEACHER RETENTION IN A LOW-INCOME DIVERSE COMMUNITY}

and are required to follow additional government regulations. The schools in Immokalee, in many ways, mirror that of the challenging urban school in which Cohen completed his study.

For this reason the researcher set the criteria to include only those teachers with at least ten years of teaching experience in Immokalee. In addition, resource personnel such as school counselors, resource teachers, administrators, and academic coaches who previously were classroom teachers in Immokalee for ten years before transitioning into a support role in the school were included. These teachers spent far more than the ten-year requirement in the classroom before moving to different roles within the school, so their insights were deemed beneficial to include in the study. In the end, the final sample included nine Collier County School personnel with at least ten years teaching experience in an Immokalee school.

Since Immokalee is a small community, the Collier County School District asked the researcher to exclude specific descriptions of teachers in the final report to protect the anonymity of the participants. This report does not include descriptions such as "a fifth grade language arts teacher with 35 years of experience" since these details could jeopardize the confidentiality of the participant. For this reason, this report includes limited information about the participants.

The sample consists of two males and seven female teachers. Eight of the nine teachers are married and all nine teachers have children. The teachers have between 13 and 25 years of teaching experience with the majority of the participants' experience greatly exceeding the criteria of ten years. All the teachers possess a Florida teaching license and one teacher is National Board certified. Eight of the participants are elementary teachers and one is a high school teacher. Six of the teachers teach at one elementary school, three at another, and one at the high school. The high school teacher had previous experience in an Immokalee elementary school before transitioning to a high school position. 


\section{TEACHER RETENTION IN A LOW-INCOME DIVERSE COMMUNITY}

Participants include both ESE and regular classroom teachers from a variety of subject areas, with the exception of physical education, music, and art. Physical education, music, and art teachers were excluded from the study because their day-to-day duties and responsibilities vary significantly from teachers of other subject areas. Responsibilities such as grading papers, preparing students for standardized testing, and the teacher's involvement with parents varies greatly from other subject areas. These teachers experience much less pressure to prepare students for the FCAT since their subject areas are not directly tested. Additionally, the nature of their subject creates a very different teaching atmosphere than teachers of other subject areas.

As stated earlier, the majority of the teachers in Immokalee commute long distances to work. This commute most likely has an impact on the retention of teachers; thus for this study it is relevant to include information regarding where the participants live and the length of their commute. Four of the subjects live in Collier County, five live in Lee County or LaBelle, and one of the subjects lives in the town of Immokalee. Three of the teachers commute less than twenty minutes to work whereas the other six commute thirty to forty-five minutes to and from work each day.

\section{Research Procedure}

Before beginning the study the researcher followed the research protocol as outlined by Collier County Schools Board. The researcher sent information regarding the study to the research department. Upon approval from the Collier County School Board the researcher submitted the necessary information to the Institutional Review Board at Cedarville University. Participants were not contacted prior to receiving approval from the Institutional Review Board. During the first quarter of the school year, all Immokalee school principals were contacted via email and asked to provide a list of teachers with at least ten years teaching experience at their school. Some of the principals provided this information directly while other principals felt 


\section{TEACHER RETENTION IN A LOW-INCOME DIVERSE COMMUNITY}

more comfortable relaying the research study information to all teachers asking those interested to contact the researcher.

There are five elementary schools in Immokalee, one middle school, and one high school. One of the elementary schools opened less than ten years ago, so there were no participants from this school. Also, there were no names for potential subjects from the middle and high school. The initial pool of possible subjects consisted of twenty-six names. These teachers were contacted via email regarding the study and were given a consent form. The consent form notified the participants that the interviews would be audio taped, that participation was voluntary, and that their confidentiality would be maintained. Of the twenty-six possible subjects eight teachers agreed to participate. Due to the relatively limited number of participants, the researcher then used the snowball sampling technique in order to receive more participants. This is a technique in which other people identify potential research participants. The researcher emailed teachers received from snowball sampling and gained one more participant, a high school teacher.

Upon agreeing to participate in the study, interviews were scheduled with each teacher. The interviews were conducted between October 2012 and January 2013. Six of the nine interviews occurred at the teacher's school site, one took place in a coffee shop, and two of the interviews were phone interviews. It was the researcher's intention to hold all interviews in person, however, due to the long commute home from Immokalee and the fact that many of the teachers teach after school programs, some of the participants were only able to participate if a phone interview was held. The interviews were approximately 30-45 minutes long. The original intent was to send the interview questions to each participant prior to the interview, but due to difficulty in scheduling interviews and with some interviews occurring with little advance notice, it was nearly impossible to send the questions to the participants with a reasonable period for 


\section{TEACHER RETENTION IN A LOW-INCOME DIVERSE COMMUNITY}

them to review the questions. For this reason, the first two participants received questions ahead of time; the remaining participants saw the questions for the first time at the interview. All interviews were audio taped and transcribed.

\section{Instrument}

The researcher collected data through standardized open-ended interviews. Interview questions were developed based on previous research. The interview consisted of fifty-five questions that addressed four categories including: The participant's background, previous education and work experience, experience teaching in Immokalee, and questions pertaining to their personal life. The questions were presented in the same order for all participants, and arranged the questions in an order that would be easy for the participants to follow. At the end of the interview, the participants were asked to share any additional comments or information they felt would be beneficial for the study. These additional and candid comments contributed greatly to the study.

Background. The background questions first sought to gather demographic information. Since the commute to work is an element in teachers' decisions to remain in Immokalee long term, the participants were asked to identify where they lived, the length of their commute to work, and if they were part of a carpool. Professional credentials / teaching license information was also collected.

Previous education and work experience. Since previous research emphasizes the importance of teachers' credentials such as their college education and teacher training, questions regarding the teachers' licensure and training were addressed. These questions focused on both their former education as a child as well as college and graduate work. Participants were asked to describe the teacher training they received at their college and whether any of their teacher training occurred in low-income, high-diversity schools. Participants were 


\section{TEACHER RETENTION IN A LOW-INCOME DIVERSE COMMUNITY}

also asked to outline their previous work experience including positions held outside the realm of education.

The study seeks to understand what led each teacher into the teaching career and more specifically to teach in an Immokalee school. The interview included questions regarding each participant's motivation to be a teacher and what events led them to the decision to work in the Immokalee schools. Participants were asked when they decided to be a teacher and in what school setting that they originally intended on teaching in. Additionally, each participant was asked to outline their previous work experience including positions held outside the realm of education.

Teaching experience in Immokalee. Participants were also asked to provide information regarding their daily work life. These questions focused on the teachers' current responsibilities in their school including additional expectations such as being a team leader or helping with after school programs. Also, questions regarding each participants teaching philosophy and teaching style were asked. Finally, other questions focused on their relationships with their colleagues, professional goals, and their perception of the part they play in children's overall education.

Personal Questions. Since previous research has highlighted the importance of the role of personal faith in those who remain in teaching positions from great lengths of time, the study included questions pertaining to participants' faith and religious beliefs and how those beliefs impact their job. Additionally, participants were asked for information regarding their involvement in activities outside of school and how they balance work and their home life.

\section{Limitations of the Study}

The researcher selected the participants from the names the principals provided to the researcher and through snowball sampling. As a result, only twenty-six names were obtained 


\section{TEACHER RETENTION IN A LOW-INCOME DIVERSE COMMUNITY}

and only nine teachers agreed to participate in the study. No names from the middle school or high school were received although one high school teacher was identified and participated in the study as a result of snowball sampling. Although this teacher was a high school teacher, they had previously taught at an elementary school in Immokalee for a number of years. Thus, all participants had experience in the elementary school setting. It was not possible to get an equal representation from each level of education and each school in Immokalee because teacher retention rates vary greatly between the schools.

Even though the sample does not include representation from all of the Immokalee schools the information gathered does provide insightful information about those who do remain in Immokalee schools for long lengths of time. This study provides a foundation to build upon and perhaps future research will expand upon these results to include a greater number or participants that more equally represent the schools in Immokalee.

It should be noted that the researcher had previously worked in an Immokalee school. This previous experience in the school has its advantages and disadvantages to the study. The researcher could approach the interviews with some understanding of the school context and teachers' responsibilities within these schools. Consequently this experience enabled the researcher to generate applicable interview questions. Rather than approaching the interviews as an outsider, the researcher was an insider and had some understanding of the daily life and work of the teachers teaching in Immokalee. This experience also has its disadvantages. First and foremost the researcher knew some of the respondents personally because they were previous coworkers. This personal relationship may have increased bias in the results because the participant may have felt the need to withhold information on certain questions or expound more information in order to please the researcher, however, excluding these respondents would reduce the sample size significantly and would have greatly limited the information gathered, 


\section{TEACHER RETENTION IN A LOW-INCOME DIVERSE COMMUNITY}

therefore, the researcher decided to include these respondents in the study. The researcher made every effort to be objective throughout the interview process, but the there is a possibility that the interviews were slightly affected due to the researcher's personal experience and interest in the subject area.

Teachers who remain in Immokalee for long lengths of time tend to be highly committed to their school and have numerous responsibilities and roles within the school. Many of the teachers have after school hour responsibilities. While all the participants answered all fifty-five questions, it is possible that some of the participants felt the need to shorten their answers due to time constraints involving their after school responsibilities. If unlimited time was available or if multiple interviews were conducted the researcher may have been able to obtain more comprehensive results.

\section{Analysis of the Study}

The researcher conducted the study through a grounded theory approach using the constant comparative method (Glaser \& Strauss, 1967). The constant comparative method encompasses back and forth interaction between the researcher and the data. When using the constant comparative method the researcher must ask questions about the data throughout the entire process. Ideas are developed and then tested with previous data or by collecting more data through follow up questions or interviews (Johnson \& Christensen, 2008). It was necessary to use the constant comparative method in this study since nine interviews were held. It would be impossible to remember main points of the interviews without constantly going back and forth between the various participants' interviews and comparing it with previous data as well as developing follow up questions to clarify and expand the results of the study. In order to implement the constant comparative method the researcher read though all of the interviews and used open coding to chunk parts of the transcript into smaller significant segments (Johnson \& 


\section{TEACHER RETENTION IN A LOW-INCOME DIVERSE COMMUNITY}

Christensen, 2008; Leech \& Onwuegbuzie, 2007). The researcher printed off the transcripts for this part of the analysis and labeled various segments with pencil / paper. This involved labeling parts of the transcripts with titles such as "teacher training," "relating to students"

circumstances," and "faith." Additionally, the transcripts were reread and axial coding was used to compare new phrases and comments with previous comments (Johnson \& Christensen, 2008). Categories were developed based upon common expressions and ideas that were found among multiple participants and similar pieces of information were given the same code (Leech \& Onwuegbuzie, 2007). With axial coding common themes or ideas from participants can be identified and relationships among the categories within the data developed. In this study similar themes and commonalities regarding the background of the teachers and their motivations for remaining in Immokalee were identified (Johnson \& Christiensen, 2008). The researcher did this by using Microsoft Word and copying and pasting different segments into one document that included a master list of all the codes. This allowed common themes from the data from various interviews to be compared at the same time. After coding the data, selective coding was used to look for main ideas and themes that support the theory being developed (Johnson \& Christensen, 2008; Leech \& Onwuegbuzie, 2007). By creating a master list of codes and determining which codes had substantial support from several of the participants, main ideas or themes were identified among several or the majority of participants. The constant comparative method can be executed deductively, inductively, or abductively (Leech \& Onwuegbuzie, 2007). This study was inductive since the codes emerged from the data as it was analyzed (Leech \& Onwuegbuzie, 2007). The researcher continued to interview teachers until theoretical saturation occurred which is when no new data emerged from the interviews (Johnson \& Christensen, 2008). 


\section{TEACHER RETENTION IN A LOW-INCOME DIVERSE COMMUNITY}

After coding the data, participants were contacted with additional questions via email in order to gain more insight into the commonalities among the teachers. These additional questions provided important information to more clearly understand the characteristics of these teachers.

In interviews, subjective words and comments can be easily misinterpreted or misunderstood. It is vital that the final analysis accurately reflects participants' comments; therefore the researcher ensured interpretive validity by using participant feedback (Johnson \& Christensen, 2008). Participant feedback clarifies and corrects miscommunication. Participants were given the opportunity to review a summary of the final analysis and results of the study. They were given the opportunity to clarify or re-word parts of the analysis that they felt did not accurately represent their thoughts and intentions. This process corrected miscommunication between the researcher and the interview participants and resulted in a more accurate and valid study.

\section{Summary}

This study is an ethnographic study which sets out to answer three primary questions: 1. What motivates teachers to continue working in an Immokalee school for long periods of time when others find this work difficult and do not remain for long lengths of time? 2. What causes these teachers to persevere and succeed in their work? 3. What background characteristics are common among long standing teachers in Immokalee? This study is ethnographic in nature with its intent to study the culture of long-standing teachers.

The use of non-probability sampling techniques included criterion and snowball sampling. School personnel with at least ten years of classroom teaching experience were used for the study. Both ESE and regular classroom teachers were included but physical education, 


\section{TEACHER RETENTION IN A LOW-INCOME DIVERSE COMMUNITY}

music, and art teachers were excluded due to the difference in their day-to-day job duties. School principals were contacted for a list of teachers who had taught in their school for at least ten years. These teachers were then contacted, by either the researcher or the principal, and asked to participate in the study. A consent form was sent via email informing the participant that the interview would be audio recorded. Once the participant agreed, an interview was scheduled. The interviews were about 30-45 minutes in length and consisted of 55 questions. The interviews were standard open-ended interviews in which the same questions were asked in the same order for all participants. All the interviews were audio-recorded and then transcribed by the researcher. The constant comparative method was used to code the data and analyze the results of the study. After coding the data, follow up questions were emailed to participants to clarify some of the data. Following this a short summary of the results of the study were emailed to participants and participants were asked to add additional comments or explain anything they felt was contradictory to their thoughts and feelings.

There were some limitations present in this study. First, the schools in Immokalee are not equally represented. There are no participants from the middle school level and only one representative from the high school. Second, the researcher had previously worked in Immokalee. This could have affected the results. Third, time was limited for the interviews since many teachers were involved in after-school programs and have family responsibilities. The information gathered in this study should help administrators make more informed decisions when hiring individuals to work in Immokalee schools or other similar school settings. 


\section{TEACHER RETENTION IN A LOW-INCOME DIVERSE COMMUNITY}

\section{Chapter 4}

\section{Results}

This chapter is an analysis of the nine interviews held with long standing Immokalee teachers. The interviews sought to address the following research questions: What background characteristics are common among long standing teachers in Immokalee? What causes these teachers to persevere and succeed in their work? What motivates teachers to continue working in an Immokalee school for long periods of time when others find this work difficult and do not remain for long lengths of time? This chapter will first outline the common background characteristics found among the nine teachers interviewed. Secondly, dissatisfying factors that surfaced throughout the interviews will be discussed to give the reader an adequate understanding of the school context in which these teachers work and what enables these teachers to remain committed to their school in Immokalee. Lastly, this chapter will discuss common themes of motivation and endurance found among the teachers.

\section{Background Characteristics}

Throughout the interviews common background characteristics emerged. Four major themes were found relating to these teachers' backgrounds. First, these teachers pursue learning opportunities and are lifelong learners. Secondly, these teachers embrace challenges. Thirdly, commonalities were found among the teachers' career decision process. The majority of the teachers decided to be teachers after pursuing another profession and none of the teachers directly pursued teaching in a low-income, high-diversity setting such as Immokalee. Fourthly, these teachers were familiar with their school context. They had other experiences in lowincome, high-diversity settings and eight of the nine teachers said that they were able to relate to their students' circumstances. 


\section{TEACHER RETENTION IN A LOW-INCOME DIVERSE COMMUNITY}

Lifelong learners. Haberman (1995) found in a study that effective urban educators are persistent and that they themselves are learners. This was certainly true among the nine teachers interviewed in Immokalee. All nine teachers demonstrated their commitment to learning and continue to learn as adults. All nine teachers interviewed attended a public school for at least part of their schooling. When asked about their experiences in school, eight of the nine teachers said that they enjoyed school as a child. Several teachers discussed the fact that they enjoyed learning. One teacher stated, "I was always with a book." This teacher also stated:

I loved learning about the world and everything. I used to look at other people and think, "Why aren't they as curious as I was about a whole bunch of stuff?" You know I just wanted to grab them by the shoulders and say, "You know this is what happens when this is happening."

As adults learning is viewed positively by these teachers and they continue to seek learning opportunities. These teachers have high academic credentials. In the State of Florida a teacher is only required to have a bachelor's degree, however, seven of the nine teachers interviewed had a master's degree. These teachers all completed their master's degree while they were full time teachers. Four teachers have either obtained a degree above the master's level or are currently working on completing it. One teacher expressed that if she had the financial assistance necessary, that she would have pursued her doctorate in education.

Additionally, five of the teachers have participated in the guided inquiry program. This is a program that schools in Immokalee do in collaboration with the University of Florida. Teachers who participate explore literature, study teacher research, and then plan an inquiry project to complete in their classrooms. When asked about professional goals one teacher stated that they wanted to, "Be able to seek as much knowledge as possible." All of these teachers set 


\section{TEACHER RETENTION IN A LOW-INCOME DIVERSE COMMUNITY}

high standards for themselves and truly are lifelong learners. This was best stated by one teacher who said, "I enjoyed going to school. School is important and again I love to learn new things, I still love to learn new things."

Embrace challenges. Cockburn (2000) found that persevering teachers embrace challenges and that a number of teachers initiated challenges by seeking a teaching job with a more difficult student population, grade level, or position. Immokalee is viewed as a more difficult population, so all of these teachers have chosen to remain in this setting. One teacher stated, "I want to stay in Immokalee. I don't know that I would love it as much (somewhere else) because it is so challenging." Additionally the desire for challenge is evidenced by the fact that many of the teachers have pursued higher education, some even above the master's level when it is not required. Cockburn also noted, that many persevering educators add additional responsibilities to their job. This is most definitely true among this group of teachers. These teachers certainly are committed to their school and students. Seven out of the nine teachers either currently hold leadership positions within the school or have in the past. These include being a team leader, a department head, and / or serving on leadership teams in the school. Additionally seven of the nine teachers are or have been involved in after school programs for the students. Several of the teachers serve in leadership positions in addition to helping with after school programs. They are very involved in their school.

Career decision. Only three of the teachers interviewed made the decision to be a teacher early in life. These three teachers mentioned how they had always wanted to be a teacher and interestingly all three of them talked about how they use to "play school" as a child. The remaining participants actually pursued a different career path prior to making the decision to be a teacher. Despite this, all the teachers expressed satisfaction with their final decision to be a 


\section{TEACHER RETENTION IN A LOW-INCOME DIVERSE COMMUNITY}

teacher. Additionally, none of the teachers pursued the idea of teaching in a low-income diverse setting. One teacher was encouraged by a previous administrator to apply, but the remaining teachers ended up in Immokalee due to other circumstances. For example, several teachers decided to teach in Immokalee because their family moved to the area and they were offered a position in an Immokalee school when they applied to work in the Collier County school district. While some of the teachers thought about the grade level they wanted to teach, none of them really thought about the socioeconomic setting they wanted to teach in.

Familiarity with school context. Former research has found that an unfamiliarity with the school environment may cause some teachers to leave a challenging school context. Dinham (1992) specifically pointed out that it is difficult for many teachers that have grown up in a middle class environment to teach in a low-income environment. Students of low SES tend to deal with a variety of challenges such as violence, divorce, homelessness, and poverty. Most of the teachers interviewed in this study were familiar with the school context.

It was evident throughout the interviews that these teachers were comfortable working in a diverse setting. Three of the teachers grew up in what would be considered a low-income, diverse setting. Two teachers were born and grew up overseas, so they had experienced moving to a new culture and experienced being the minority. It is also interesting to note that the topic of civil rights and social equality surfaced in three of the interviews. One teacher was very political and discussed her involvement during the Civil Rights movement and her strong interest and commitment to equality. Another teacher discussed her memories of her school being desegregated and forced busing being implemented. This teacher expressed that she had taken several classes in social equality and found it very interesting. Another teacher discussed her personal experience with discrimination and how it affected her as a child in school. She stated: 


\section{TEACHER RETENTION IN A LOW-INCOME DIVERSE COMMUNITY}

We were the only black students in the whole school. We integrated the school and then when we left it re-segregated, and basically the teachers just didn't know how to, they had no experience with black children. They didn't know they were being ignorant and insensitive.

Inman and Marlow (2004) suggested that since it is difficult for teachers to teach in unfamiliar school environments it is vital that teacher education programs adequately prepare teacher candidates by providing teaching experience in a variety of school contexts.

Interestingly, all but one of the teachers interviewed in this study had experience teaching in lowincome, diverse settings during their teacher training or prior to their employment in Immokalee and three teachers taught overseas before teaching in Immokalee. One teacher stated:

I have not done any teaching that was not in a low-income school. I never actually had any experience in a school that was not. My internship all of my teaching years have been in low-income high-diversity schools.

Another teacher explained that her experience teaching in a low-income school environment is actually what she believes led her to spend her career in a low-income setting. She stated:

I just fell in love with the kids, the parents, and the families, and it ended up being a wonderful experience which is probably why I've gravitated towards spending my whole career in Title I schools because it was such a good experience.

The majority of the teachers in this study stated that they could relate to their students' circumstances in some way. They had experienced similar struggles throughout their life. Only one out of the nine teachers stated that they were not able to relate to their students' circumstances personally. She described her first visit to Immokalee by saying: 


\section{TEACHER RETENTION IN A LOW-INCOME DIVERSE COMMUNITY}

It was not like where I had come from before, and my first drive through town in Immokalee I was like, "What have I gotten myself into?” But I did take the job and that's the only interview I've ever done.

Despite this teachers' unfamiliarity with the environment she has remained committed to teaching in this setting. This teacher went on to say that while she was unable to relate to the struggles of her students, she could understand their situations and could emphasize with them. Additionally, while this teacher could not relate to the students on a personal level it is interesting to note that her internship was done in a low-income high-diversity setting.

The remainder of the teachers interviewed were able to point to specific experiences in their lives that were similar to those of their students. Two of the nine teachers actually grew up in Immokalee and went through the Immokalee school system. These teachers expressed that they could relate and understand their students' situations very well since they grew up in the same community. One of these teachers stated, "I feel that I can tie in and bond with them so well because I feel like I've been in their footsteps before. I've been there and I have experienced life just like they are experiencing life now." Both of the teachers from Immokalee explained that they feel they have a unique responsibility to be role models for their students of a person from Immokalee who did go through school and was successful. One teacher stated, "I feel that the children here need more people that have been raised here, born here, and are home grown ... it's a great experience for them to see that they can also be someone and something

one day." The other teacher from Immokalee said something very similar, "They kind of look up to me in a way."

Several teachers explained the difficulty they had experienced in settings where they did not speak the language. One stated: 


\section{TEACHER RETENTION IN A LOW-INCOME DIVERSE COMMUNITY}

I've lived in foreign countries, so I understand what it's like going to a supermarket and looking at cans and not knowing what's inside because I can't read the contents or I don't know how the system operates and I don't know things that are acceptable and aren't acceptable. I feel that I can connect with my students in that way as well and their families that way because I know what it's like to give up familiar surroundings and family and friends and stuff and kind of immerse yourself in a different culture.

Another teacher explained that she could relate to the struggles English Language Learners (ELL) faced since her first language was not English. This teacher stated, "I didn't speak any English. My first language was Spanish and I really didn't acquire English until I was about 11 or 12 years old." Another teacher said that she could relate because her parents were immigrants.

Some teachers explained their struggles growing up in a low socioeconomic setting. They could relate to the economic conditions of their students. One teacher stated, "The school where we were it was definitely out of the area where I lived we were definitely the poor children in a middle class environment .. . I lived in public housing." Another teacher discussed the difficulty her family faced. She said, "I never had all the things that a lot of my peers did. One teacher said, "We were quite poor ... we lived in very poor circumstances."

\section{Dissatisfying Factors}

Throughout the interviews teachers spoke of the different challenges they faced while teaching in Immokalee. Among the teachers there seemed to be four dissatisfying factors that arose. These included: insufficient time, the negative perception directed towards Immokalee, working with parents who, for the most part, have limited education and English language skills, and standardized testing. 


\section{TEACHER RETENTION IN A LOW-INCOME DIVERSE COMMUNITY}

Insufficient time. In a study by Moriarty et al. (2001) teachers of young children in England, specifically those with more experience, stated that they had difficulty completing the additional work required due to the constant changes in education, and some communicated that these changes negatively impacted their classroom teaching. In this study three teachers discussed how they did not have enough time to complete everything required for their job and that the constant demand to get everything done in a limited time frame was dissatisfying. When one teacher was asked what she finds the most stressful about her job, she replied by saying,

The pace, the huge number of things that have to be done in one day. You know it's just constant there's no let up, and I find that upsetting. I mean, I like the times when as a team we can sit and just have those conversations, almost leisurely conversations, and talk about an issue or a child or a curriculum piece or whatever and just spend time talking about it and hashing it over, and you don't. There's always a clock ticking and that's very stressful.

Another teacher replied by saying, "The time. There's no time to do everything that everyone wants done." One other teacher's response was, "Lack of sleep."

Negative perception of Immokalee. As stated earlier the OECD (2011) pointed out that countries that have been successful at making teaching an appealing profession did so not solely by raising teacher pay, but also by improving the status of teaching, treating teachers as professionals, and involving them in the reform process. Society's criticism of teachers is a source of dissatisfaction for teachers (Dinham 1992). This was certainly true in this study. The negativity was not directed at the teaching profession in general, but rather pointed at the decision to teach in the community of Immokalee. All but two teachers expressed that they had experienced negative reactions from people when they told the person they taught in Immokalee. 


\section{TEACHER RETENTION IN A LOW-INCOME DIVERSE COMMUNITY}

In fact, two teachers stated that they heard these negative comments from other school personnel within the district at professional development trainings.

The two teachers who are native to Immokalee did not mention receiving any negative reactions from others when they told them they taught in Immokalee. In fact these two teachers experienced the exact opposite. These teachers expressed that others were very proud of their decision to work in Immokalee and respected them for it. One teacher stated that others were, "Happy that they had a family member that was in education, you know to kind of talk to if they had any questions in regards to their kids." The other teacher expressed that others respect him for teaching in Immokalee since there is a great need for people who have grown up and lived in Immokalee.

The remainder of the teachers have experienced negativity from those around them about their choice to teach in Immokalee. The negativity seems to stem primarily from people outside their families, especially strangers. One teacher stated, "Family is supportive and they're used to it by now sometimes strangers or people I don't know very well will ask me, 'oh you teach in Immokalee,' and they kind of give me that funny look." The teacher went on to explain that one day after school she was out in public wearing her school staff shirt and a stranger looked at her and stated, "Oh you work at that failing school in Immokalee. Why would you want to work there?" Several participants discussed how others are fearful of Immokalee and refused to visit Immokalee even when they were invited by one of the teachers in this study.

A few teachers expressed their frustration with the negative perception of Immokalee portrayed in the media. One teacher stated, "A lot of people are fearful of the unknown and all they get is what's in the media." Another teacher explained the frustration she feels because of the recognition that other schools receive. She stated: 


\section{TEACHER RETENTION IN A LOW-INCOME DIVERSE COMMUNITY}

Then you see people who are at A schools that are always A schools, and I know it's hard to maintain an A and its terrible to lose an A I'm sure and you think well we're working just as hard as they are but they get celebrated and they get recognized in the news and we don't so that's frustrating.

Interestingly the negativity from the media, community, and even fellow educators actually motivates some teachers to be an "ambassador" for Immokalee. One teacher stated, "I kind of feel like an ambassador for Immokalee. I know some teachers are afraid to come ... I just wish they would come and visit and go around and just know that it's not that bad." Another stated that they feel it is their responsibility to promote Immokalee in a positive way. This teacher stated:

I used to get really upset and you know I was that one person who would call and say, "Hey I can't believe you said that on the news, or did you seriously write that article?" You know I feel that my job is to put a positive face on that community as often as possible.

While the negativity is somewhat discouraging for these teachers, it does not seem to impede their commitment to Immokalee, rather it motivates them to become an active voice and "ambassador" for the students and schools in Immokalee.

Standardized testing. Four teachers discussed their frustrations with standardized testing, in particular the amount of standardized testing that the students are required to participate in. Teachers discussed the fact that the expectations are often too high for students and that it has taken the fun out of learning and teaching. One teacher stated:

I think the most challenging of course is our high stakes test. Not because our kids are ELL learners or Exceptional Student Education (ESE) or any of that, I feel the challenge 


\section{TEACHER RETENTION IN A LOW-INCOME DIVERSE COMMUNITY}

is more in the hands of the people that are dictating these benchmarks and requirements, rather I feel our kids, my kids are normal. It's the expectations that are blown out of proportion.

Another teacher expressed similar frustrations with standardized testing. She stated:

The first twenty years of my teaching I liked my job a lot. There weren't any benchmark tests, there was no Florida Comprehensive Assessment Test (FCAT). The kids took a standardized test at the end of the year. There wasn't any stress for the students. There wasn't any stress for the teachers. It was just do the best you can. Back then teaching was fun. My philosophy is that teaching should be fun, and I think we've taken that away a lot from our kids.

One teacher expressed her frustration with the fact that she believes her students have made learning gains, but that it is not always reflected in the test scores. She stated, "It's just frustrating because you know how hard you work and you don't see it reflected in the test scores." One teacher discussed the stress that FCAT causes her. When asked what's most stressful about her job one teacher expressed her concerns for those students who hadn't passed the FCAT. She stated, "Those individual kids stress me out because I'm invested in their lives."

\section{Communication with parents who have limited education and English language}

skills. Three teachers spoke about the challenge of dealing with parents who are not highly educated and parents in which English may not be their first language. In almost all cases, the interaction with parents was positive, however, it was challenging working with parents within a language barrier and with parents, who despite their desires and intentions, cannot provide much support at home. One teacher stated: 


\section{TEACHER RETENTION IN A LOW-INCOME DIVERSE COMMUNITY}

I think it's the language barrier of the parents ... and the children a lot of them are second language learners. Their first language is either Haitian Creole or Spanish, and when they go home they're exposed to nothing but their home language which is either Haitian Creole or Spanish. That means that they don't have the guidance that they need to do homework, and so they don't know what they're doing . . . Not that they don't care because they work so hard. I mean some of them have two or three jobs and are not home during the day or at night. See so that's the thing because I feel that if the parents were more involved because they were able to, maybe with the language not being a hindrance the children could have much more success.

Another teacher stated something similar:

A lot of the parents are not as educated as at other schools, and so not having too much support at home, they might support them with love, but as far as having educated parents at home that really know what's going on at school and can help out with homework is something that's a bit challenging.

Finally another teacher said, "Many of the parents that come from many foreign countries, from Mexico or Haiti or Jamaica. They don't have the background knowledge in education." These teachers find that their job is more challenging because they do not have as much academic support from the home. This is not to be confused with the idea that the teachers have a poor relationship with the parents because the opposite is true. It will be discussed later that the relationship between teachers and parents is strong in Immokalee. Parents and teachers work together well and support each other in every way they can, however, it is just not possible for the majority of the parents to provide academic support for their children due to their limited education and their inability to speak English. Several of the teachers made a point to express 


\section{TEACHER RETENTION IN A LOW-INCOME DIVERSE COMMUNITY}

that the parents' desire to help and support their child's education is present, yet they often don't have the English skills or education necessary to help their child with academics.

\section{Themes of Endurance}

It was evident that despite the challenges, which undoubtedly surfaced during the interviews, each teacher exemplified a sound commitment to their current position as well as the students and community of Immokalee. A general sense of contentment and satisfaction with the decision to spend a great amount of their career in Immokalee were expressed by all. Five teachers expressed their contentment strongly by stating that they "loved" their school and / or the population of Immokalee.

One teacher said:

I'm very, very, very, very, very happy where I am. Very, very, very happy. I feel like I have the best job in the school. I feel like I work in the best school in the district. I love it here. I wouldn't want to leave.

One teacher expressed her loyalty to her particular school when she stated, “I don't know how I would fall in love with another school and not always be thinking that I' $m$ in competition with this school." Another said, "Literally I love working here." Another said, "I love everything about teaching in Immokalee." One other teacher showed her love for the students by stating, "I love the kids of Immokalee."

While these teachers were open to sharing the dissatisfying elements of their job, they clearly emphasized that they enjoy teaching in this setting. What elements of motivation inspire these teachers to be so committed to their job? Several common themes of endurance were found among the teachers. 


\section{TEACHER RETENTION IN A LOW-INCOME DIVERSE COMMUNITY}

Making a difference in students' lives. Stanford (2011) found that urban teachers' desire to have a positive influence on their students' personal and academic growth motivated them to continue teaching for great lengths of time. Additionally Cockburn (2000) found that working with students was the prominent reason elementary teachers remained in their jobs. The desire to make an impact and difference in students' lives was the primary motivation of the teachers interviewed in this study to continue working in Immokalee. Eight of the nine teachers talked about the sense of satisfaction they feel from watching their students succeed academically. This success could be small steps towards improvement, not necessarily huge momentous achievements. One teacher said, "If they learn one thing throughout that day I feel that they've learned something new so that to me is very, very meaningful." All the teachers seem highly motivated to see their students make progress. One teacher stated:

I have to make a difference. If I feel that I have not made a difference in bringing that child's FCAT score from a one to a two I think maybe there was more that I could have done or maybe I could have done something a bit differently.

Another teacher stated that seeing his students meet their annual goal keeps him wanting to strive to be better for them. This teacher also stated, "Coming to school and being here and seeing at least an "ah-ha moment" or something from a student, you know it just makes it all worth it." Similarly when asked to describe a successful day at school another teacher stated, "When light bulbs go off you know."

Teachers not only spoke about the academic achievement of their students but also about the difference they desire to make in their students character and personal growth. One teacher actually made a point to say, "I also believe in teaching them life lessons to hopefully make that difference in their lives." Several teachers talked about the fact that they hope they make a 


\section{TEACHER RETENTION IN A LOW-INCOME DIVERSE COMMUNITY}

difference in students' lives by being a role model for students, particularly of a person who made it through tough situations. One teacher said, "I think it's important that they see someone who came from a single parent home ... who didn't speak English and who made it. I chose a different lifestyle. I chose a different way of life than my parents did." One teacher talked about the importance of being a father figure for many of his students. He stated, "Many of them have only one parent and that's pretty sad, and as their teacher I feel that I can tie in and bond with them because I can help them." Similarly another teacher felt like they were a good example to students. He stated, “They kind of look up to me in a way being a male cause there's not a lot of male Hispanic teachers is one, being from Immokalee too." One teacher summarized it well by saying,

It makes me feel like I make a difference and I know that our students live in poverty, and I like to think that I've taught them something that will help them in the future.

Whenever I get a chance, or the subject comes up, I try to teach the kids the types of jobs and professions that are out there because so many of them hear the standard response doctor, teacher, and lawyer. All I hear is football player. I want to be a football player or a dancer which is fine, but I try to tell them that there are lots of other things and lots of other choices out there.

Above all else, it is this desire to make a difference in students' lives that motivates these teachers to continue in their current position. One teacher summed it up best when she was asked whether or not she made a difference in students' lives by saying, "I like to think I do. That's what puts my pedal to the metal every morning." 


\section{TEACHER RETENTION IN A LOW-INCOME DIVERSE COMMUNITY}

When the teachers were asked what was most rewarding about teaching in Immokalee four of them responded by saying that kids coming back to visit them years later was very rewarding. One teacher stated,

When I have children who come back to see me after ten years or twelve or graduating or are in college or parents or whatever and they'll come back and I can remember who they are and they remember who I am and its lovely.

One teacher stated:

Most rewarding is when the parents thank you, the parents years later. Now which one is it, the parents or the children? Because when I go to the high school and the middle school and I see the children ... They'll remember one of my math songs when they're in high school that I made up on the top of my head. I'll say, "Sing it for me," and they'll be able to sing it, or they'll remember something that I'd long forgotten . . . and they've taken it on to high school. One time my mom met a parent, a parent of a student, and she was going on about how, "I remember Mrs. Curry. She went above and beyond for my daughter and we really appreciate it."

Similarly another teacher stated:

When I see those kids that are now grown adults come back and say, "You know what you were tough on me, but you loved me and it showed. You made me want to be a better person." To me that's what motivates me, and I know people say that all the time but ... that's what does it for me.

Recognizing that they have made a difference in students' lives brings these teachers satisfaction and drives them to continue in their work. 


\section{TEACHER RETENTION IN A LOW-INCOME DIVERSE COMMUNITY}

Supportive school environment. Although, there did not seem to be a strong theme of assigned mentors all the teachers said that they had other individuals they could go to for support. Each teacher interviewed spoke positively of their relationships with others at the school and the support they received. Day and Gu (2009) stated that teachers in all countries need to be well-supported in order to survive the constant demand of government reform. This is certainly true in Title I schools where there is much more government reform.

A common theme found through all the interviews was a willingness to work with others and collaborate with other teachers. All the teachers spoke of how they regularly go to other teachers for support, advice, and to discuss strategies and ways to help their students. There tended to be a strong sense of camaraderie between the teachers. One teacher stated:

People are available every day, and I could be in and out of Mrs. Peter's office maybe more than twice a day because I came from fourth grade and I need a strategy or something ... It's ongoing every day, whenever, and people are very open and very helpful at school because you know it's all about team work.

When one teacher was asked how often she went to coworkers for support she stated, “Whenever needed I mean I just, I don't hesitate. I can’t tell you how many times." Another teacher stated, "Yes I think our whole building are actually teachers here are willing to give a helping hand to go beyond the jurisdiction to help anyone, so I feel that we are very strong in that category." Another teacher said, "We're always working together to implement skills and strategies to help our kids be successful."

Several of the participants mentioned the fact that it was important that they work together as a team and how everybody in the school is responsible for the students' success. One teacher said, "You know we're stake holders of our kids you know and that's how it's been 


\section{TEACHER RETENTION IN A LOW-INCOME DIVERSE COMMUNITY}

instilled in us here that everyone's responsible for everybody." Another teacher said, it was an "all hands on deck" mentality. Another teacher stated, "One cannot do without the other it's teamwork."

Many teachers talked positively about the relationships they have with others at their school. All nine teachers said that they had friends at work and many of them spoke of activities they actually did outside of school with their friends. All nine teachers expressed that they had built positive relationships with their co-workers and enjoyed working with them. There seemed to be a "family" atmosphere. One teacher said, "I feel loved here." In fact, several stated that their relationships with others at their school has been a motivator to continue working there. One teacher stated that they decided to stay at their current school because they had found a "comfort zone" at their school and because they had "good rapport with the staff and administration." Another teacher said, "I've been privileged to work with a lot of good people and especially in Immokalee." She went on to say, "I guess it's one of the more fortunate schools and that's probably largely one of the reasons I'm still there because we all work together so well." Similarly another teacher stated:

An inordinate amount of people have stayed at our school and commuted long distances for a long time, and I do think it's because the relationships we've built here with each other and kind of going through it all together that kind of a thing. I think here at our school this year, I think only two people live in Immokalee all the rest commute and have for a long long time. So I think that that sense of community that that building of relationships really helps.

When asked what she enjoyed most about teaching in Immokalee one teacher replied by saying, "The camaraderie at this school." 


\section{TEACHER RETENTION IN A LOW-INCOME DIVERSE COMMUNITY}

Faith. Similar to Stanford's findings, faith seemed to play a critical role in many of these teachers' lives. In fact, eight out the nine teachers expressed that they participated in faith activities. One teacher stated that she felt like teaching in Immokalee was her "calling” or "mission work." Prayer seemed to be an important aspect of their faith. One teacher stated, "I wouldn't begin starting my day without a prayer. My first prayer of the day is to get me safely there ... and then after that I pray for students, I pray for myself, yes my faith is very important." Many teachers expressed that their faith helps them get through various trial and tribulations, both their own trials as well as their students. One teacher explained that prayer helps her deal with those heartbreaking situations. This teacher stated, "Well that's probably how my faith probably comes in hand. I pray about it a lot because it's heart breaking." One teacher stated:

I have to be in prayer every day because when I walk into my classroom I have kids that come from all different walks of life that come from different circumstances that are experiencing different crisis in their lives and if I'm not what I call "prayed up" you know and if I'm not investing my time in God's word and seeking direction then how can I lead them?

Other teachers discussed how their faith helped them personally become a better person and better role model for their students.

Boundary between work and school. While all the teachers seemed very dedicated to their work, and many participated in after-school programs, all but three spoke about how there was a boundary between their work life and their home life. This boundary looked different for each teacher, but they had thoughtfully considered the best way to distinguish their time at work from their time at home. One teacher discussed how when she had young children she would not 


\section{TEACHER RETENTION IN A LOW-INCOME DIVERSE COMMUNITY}

do any school work until her children were in bed at night. Another teacher discussed that she rarely takes school work home. She used the analogy, "We don't bring our laundry to fold at school, so why do we take our school work to do at home?" She went on to explain how while she is at school she uses her time wisely so that she can accomplish as much as she can during her school day. Interestingly a couple of teachers explained that their commute to and from work actually helped them transition from being at work to being at home. One teacher stated, "I believe once I take that long drive from Immokalee I switch off because I've given one-hundred percent of myself." Similarly another teacher stated:

Well I've always found that commute has helped me a lot cause I have to switch my hat when my children were little. I'd have to switch off the "my teacher hat" and become mom and that gave me the time to do that. At the same time coming into school I quit being mom and I could become "teacher."

It may be, as prior research has indicated, that this barrier between work and home life prevents these teachers from experiencing burnout and gives them more energy and enthusiasm for their work when they are at school.

Bureaucracy on the outskirts of job. Although bureaucracies were another source of dissatisfaction, most of the teachers were able to dismiss them and set up a boundary between their work and bureaucracies. The common theme among the teachers was that most of them seemed to stay "under the radar." Many of the teachers tried to avoid bureaucracies. They do what's necessary, but they do not let it become the focus of their attention. When asked how they deal with bureaucracies, one teacher stated, “I ignore them. That's not my job I'm a classroom teacher that's their job." Another teacher said something similar, "I try and stay under 


\section{TEACHER RETENTION IN A LOW-INCOME DIVERSE COMMUNITY}

the radar." Another teacher stated, "I address it from that standpoint of, ok this is required I have to jump through this hoop and I do it."

Another teacher stated,

There's only so much you can do your voice is very small and the only big voice is the union's voice ... we just have to put up with what is already is in place because all it comes down to is money.

Lastly one teacher stated, "I try to put all those things in the outskirts." Similar to the barrier between home and work that most of the teachers identified, it appears that a similar barrier is created in their mind in regards to bureaucracy. The teachers are careful to complete what is required, but they don't allow the frustrations of government reform and federal mandates to dominate their thinking and day to day work.

View students as individuals. A common theme was found among the teachers in that they seemed to view their students as individuals rather than the group or class. This is interesting to note since much of the emphasis in schools right now is improving school grades and teachers evaluations and pay are now being based on their class' improvement, nonetheless, it seems that the teachers are less concerned with this and more concerned with the individual improvement of each student. One teacher stated, "I don't worry so much about the school picture. I know I should but to me no it's those individuals."

The teachers seem to view their students' progress and achievement on an individual basis as well. They set realistic goals and hold their students accountable by setting high standards, but they do not expect all of their students to make the same academic gains. One teacher stated, "I really want every child to reach their potential and I do believe that not everyone's potential is the same." Another teacher stated: 


\section{TEACHER RETENTION IN A LOW-INCOME DIVERSE COMMUNITY}

Not everybody's going to go to college and not everybody needs to be factory worker and not everybody needs to be a field worker, but if we didn't have all three of them you know we would not have a country that could take care of itself.

Another teacher said, "We can't expect more than that child can give, and we have to teach thinking about that all the time. We have to be able to differentiate all the time."

Differentiation was a regular practice of these teachers. One teacher stated, "We all work at our own pace we have different learning styles." Another teacher stated, "I kind of teach from their strengths or their interest." Perhaps it is these teachers' willingness to cater their instruction to meet the individual needs of their students that allows them to be successful at what they do and continue in their current work. In an environment such as Immokalee where kids are at all different academic levels and have all different levels of English speaking abilities, the ability to adapt instruction to meet their needs is crucial. These teachers are willing to differentiate and see it as a key component of their daily work.

Strong relationships with parents and family. Perie and Baker (1997) found that when positive interaction with parents took place in schools, it increased teacher satisfaction. One strong finding in this study is that many teachers spoke very positively about the relationship they held with their students' parents. While many of them discussed the challenges they had dealing with parents with limited education English language skills, they did not speak negatively of the relationship they had with the parents. In fact, when asked what motivated them to continue teaching in Immokalee one teacher responded by saying: "As I've said before it's the parents and the students themselves." Research has indicated that positive interaction with parents increases teacher satisfaction. While several of the teachers mentioned the challenges they faced dealing with parents in Immokalee due to their limited English and 


\section{TEACHER RETENTION IN A LOW-INCOME DIVERSE COMMUNITY}

education level, it is apparent that overall the interaction between parents and teachers is positive. One teacher expressed that one reason she remains in Immokalee is because she does not know whether she would enjoy the "different dynamic of having the parents not always be supportive."

It appears that some of the teachers have been in Immokalee long enough to establish relationships with students' other family members and have had the opportunity to watch their students grow up through their school. One teacher expressed this by saying:

I know their siblings I know their cousins I know their parents. You know I've known them since they were in carriages and strollers and stuff like that and I think it's really important you know for parents to come here and let them feel welcome, and I really try to go out of my way to do that. So I think I have a good relationship with the parents.

\section{Conclusion}

While Immokalee certainly is a challenging environment in which to teach there are some teachers who choose to stay in such an environment and are content to do so. These nine teachers all expressed their love for the students, families, and community of Immokalee. Although they were willing to discuss the challenges that they deal with each day, their overall experience was positive. Several key characteristics were identified among these nine persevering teachers. Concerning background characteristics, it was evident that these teachers were all lifelong learners. They sought learning opportunities and desired to become as knowledgeable about their profession as possible. Seven out of the nine teachers have at least a masters' degree. These teachers also embrace challenges. They are not afraid to work hard but rather are driven by hard work to perform better and accomplish more. Interestingly, the majority of the teachers pursued another career before choosing to become a teacher. None of 


\section{TEACHER RETENTION IN A LOW-INCOME DIVERSE COMMUNITY}

the teachers directly pursued working in a low-income school environment but rather ended up in Immokalee due to circumstantial reasons. Most of the teachers were familiar with their school context. They had experienced similar struggles growing up and therefore had the ability to understand and empathize with their students.

Four dissatisfying factors seemed to be key in creating stress and frustration among the teachers in Immokalee. First, limited time prevents these teachers from being able to do what's necessary to do their job to its full potential. Secondly, many of the teachers experience a negative perception directed at them and their decision to teach in the community of Immokalee. Rather than being encouraged by others, they experienced mostly discouragement. Thirdly, standardized testing and state expectations for the students' progress were dissatisfying for teachers. Lastly, communication largely with parents who have limited education and limited English skills is a regular challenge for these teachers.

Despite the challenges faced, all of the teachers expressed a sense of contentment with their job. Seven themes or endurance were found among the teachers. The primary motivation for these teachers to continue teaching in Immokalee is the desire to make a difference in their students' lives. Observing students progress academically and monitoring their character motivates these teachers. Students returning years later to visit was one of the most rewarding aspects of the job for several teachers. These teachers also had a strong support system within their school. There was a sense of camaraderie among the staff and a willingness to help others. While few of the teachers discussed official mentors as being pertinent to their support system, all of the teachers had established relationships with people in their school who they could go to regularly for support and assistance. Many of the teachers spoke of friendships they had established with co-workers and actually participated in activities outside of school with these 


\section{TEACHER RETENTION IN A LOW-INCOME DIVERSE COMMUNITY}

friends. Another common theme among the teachers was that eight out of the nine teachers were involved in faith activities in some way and discussed relying upon their faith to help them through challenging circumstances at school. Several teachers discussed praying for their students and themselves and expressed that this was key to their success as an educator. Interestingly, all but three teachers had established some sort of boundary between their school life and home life. These teachers did not allow bureaucracies to dominate their thinking. While many teachers found bureaucracies frustrating, they did not focus on this. Almost all of the teachers look at their students' individually. They desire to see each individual student make progress and are willing to differentiate their instruction to meet the needs of the individual students in their lives. Lastly, these teachers had positive relationships with their students' parents and in some cases even their extended families. Relationships were a key part to their job. These factors of endurance are what allows these educators to be successful in their job and remain for inordinately long periods of time in Immokalee. 


\section{TEACHER RETENTION IN A LOW-INCOME DIVERSE COMMUNITY}

\section{Chapter 5}

\section{Discussion}

The purpose of this study is to determine characteristics and motivations of teachers who remain in Immokalee for long periods of time. The Immokalee schools consist of a diverse population of students, many of whom are from low-socioeconomic families. All the public schools in Immokalee are Title I schools. Previous research indicates that high-poverty, highminority schools have a difficult time recruiting and retaining teachers (Elfers et al., 2006; Goldhaber et al., 2011). In a country in which education leaders are striving to improve the quality of education for all students in America, it is imperative that Title I schools recruit and retain highly qualified teachers. Teacher effectiveness is one of the most important factors of student success (Darling-Hammond, 2007; Rockoff, 2004) and teacher experience greatly contributes to their effectiveness (Clotfelter et al., 2006). Therefore, if the education is going to be improved in these school settings, it is vital that these schools not only recruit highly qualified teachers, but also teachers who remain for extended periods of time. The purpose of this study is to determine common characteristics among long-standing teachers in Immokalee so that informed decisions can be made when hiring individuals to fill vacant teaching positions. Additionally, this study sought to determine ways in which the district can support teachers in Immokalee and create a positive working environment in which teachers desire to stay for long periods of time.

This study was an inductive qualitative research study. Nine standard open-ended interviews were conducted with teachers who have remained in an Immokalee school for more than ten years. The interviews sought to answer the following research questions: What motivates teachers to continue working in an Immokalee school for long periods of time when 


\section{TEACHER RETENTION IN A LOW-INCOME DIVERSE COMMUNITY}

others find this work difficult and do not remain for long lengths of time? What causes these teachers to persevere and succeed at their work? What background characteristics are common among long-standing teachers in Immokalee? School principals in Immokalee were asked to provide names of teachers who have taught in Immokalee for at least ten years. Interviews were scheduled with these teachers and occurred between October and January of the 2012-2013 school year. The interviews occurred primarily at the teachers' schools in Immokalee. All the interviews were about thirty to forty-five minutes in length.

The participants were asked to questions that address four categories of information including: the participants' background, previous work experience, experience in Immokalee, and questions pertaining to the participants' personal life. The background questions sought to gather information regarding demographics including where the participant lived, the length of their commute to Immokalee, whether or not they participated in a carpool, and licensure credentials. The participants were asked questions regarding their previous work and education experience. These questions addressed the participants' former education, college and graduate work, teacher training, and questions regarding their decision to become a teacher. Also, questions regarding the participants' experience in Immokalee were presented. Teachers described their daily work life, participation in additional school activities, teaching philosophy, teaching style, professional goals, the role they play in children's education, and their relationship with colleagues. Finally, questions were asked pertaining to the participants' personal life including their religious beliefs and involvement in activities outside of school.

Each interview was audio recorded and transcribed using the constant comparative method. The purpose was to uncover common themes found among the nine interviews. After coding the data, the participants were emailed follow up questions that clarified or elaborated on 


\section{TEACHER RETENTION IN A LOW-INCOME DIVERSE COMMUNITY}

some of the points they made during the interview. Lastly, a summary of the interview data was sent to participants and asked them to clarify any portions of the report that were contradictory from what they intended to communicate.

The researcher gathered much information from these interviews regarding the teachers' backgrounds and experiences in Immokalee. Several common background characteristics, dissatisfying factors, and themes of endurance were identified among the teachers. Regarding background characteristics each of the teachers pursue learning opportunities and are life-long learners. This pursuit of learning opportunities is done voluntarily, not out of duty to fulfill job obligations. These teachers also embrace challenges. They seek opportunities to expand their experience and skills. These teachers are greatly involved in school activities including afterschool programs and serving in leadership roles. Interestingly, the majority of the teachers in this study decided to be a teacher after pursuing another profession, and none of the teachers directly pursued teaching in a low-income, high-diversity setting such as Immokalee. Each ended up in Immokalee due to life circumstances. Perhaps the most pertinent finding regarding these teachers' backgrounds is that the majority of them were familiar with their school context and could relate to their students' circumstances in some way.

All the teachers expressed that they were content with their current position in Immokalee. They expressed a love for the students, parents, and community of Immokalee, but there were several common factors that caused dissatisfaction among these teachers. First, these teachers find that there is rarely enough time to accomplish the many tasks required in a given day. Limited time seems to increase stress among these teachers and causes job dissatisfaction. Second, the majority of the teachers communicated that others had made negative comments directed at their decision to teach in Immokalee and that overall the surrounding community has 


\section{TEACHER RETENTION IN A LOW-INCOME DIVERSE COMMUNITY}

a negative perception of Immokalee. Third, standardized testing and the academic expectations required of the students causes dissatisfaction. Many teachers feel that the expectations do not take into consideration the unique circumstances of the students in Immokalee. Several teachers expressed frustration with the fact that their students' progress often is not reflected in test scores and that they are rarely recognized for their achievements. Finally, while the relationships between parents and teachers in Immokalee is primarily positive, several teachers expressed the challenges they experience when attempting to communicate with parents.

Several themes of endurance were found among the teachers in Immokalee. First these teachers receive great satisfaction from knowing that they are making a difference in students' lives. This seems to be the primary motivation for these teachers to continue with their work. In addition, all of these teachers talked about the fact that they are well supported at their school and that they have established positive relationships with other teachers and personnel in the school. Many of them have developed friendships with those at school and from time to time participate in social activities outside of school with these people. All but one of the teachers said that they participate in faith activities and that their faith is important to them. The majority of the teachers have created some sort of boundary between work and home. Although this boundary looks different for each individual, they all find a way to balance their time at home and their work responsibilities. Also, these teachers keep bureaucracies on the outskirts of their job. They do not allow the frustrations of these to dominate their thinking. Interestingly, these teachers view their students as individuals and set reasonable goals and expectations for their individual students. They are willing to differentiate their instruction to meet the needs of the individual students in their class and are flexible with their instruction. Lastly, these teachers speak positively about their relationship with their students' parents and in some cases their 


\section{TEACHER RETENTION IN A LOW-INCOME DIVERSE COMMUNITY}

students' extended family. They expressed a willingness to work with parents in order to help their students be successful.

Based upon these findings several recommendations can be made that may assist the Collier County school district in both hiring individuals to teach in Immokalee and creating workplace conditions that will improve the retention rate of these teachers. First, are

recommendations regarding hiring teachers to teach in the Immokalee schools. Second, are ways to improve the retention of teachers in Immokalee. In addition, suggestions for further research are presented as well as how the results of this study pertain to those with a Christian worldview.

\section{Recommendations Regarding the Hiring of Immokalee Teachers}

\section{Hire Teachers who are Life-Long Learners}

When hiring teachers to teach in the Immokalee schools, there are several characteristics that principals should consider throughout the hiring process. All the teachers interviewed in this study are what would be considered life-long learners and they continue to seek learning opportunities throughout adulthood. They are hard workers, have high academic credentials, and willingly participate in activities such as guided inquiry. These findings indicate that principals should seek to hire candidates with high academic credentials including advanced degrees. They should also pursue candidates who continue to participate in learning opportunities. Most of the teachers in this study were involved in after-school programs, and all have held leadership positions at some point throughout their time in Immokalee. Principals should seek candidates that have held leadership positions at their previous school and have demonstrated a great amount of involvement in school activities. When considering new college graduates it would be beneficial for principals to consider the applicants involvement in their university. Did they participate in any leadership positions? Were they involved in campus organizations? Were 


\section{TEACHER RETENTION IN A LOW-INCOME DIVERSE COMMUNITY}

they involved in their community? Most of the long-standing teachers in this study are greatly involved in their school and demonstrate strong leadership skills.

\section{Work Together with Area Universities to Recruit Teachers}

The Immokalee schools have already established a relationship with the University of Florida through their guided inquiry program. Since there is strong evidence from this study that experience during teacher training in low-income school settings increases retention, the schools in Immokalee should work with surrounding universities to provide opportunities for student teachers to spend time in the Immokalee schools. Exposing pre-service teachers to the challenges as well as the rewards of working in the Immokalee community may motivate some to consider such an option. These pre-service teachers would get first-hand experience and would have the opportunity to observe and work alongside a well-experienced teacher before entering a similar classroom experience. Even those students who do not think they are interested in teaching in a community such as Immokalee could benefit from spending some time in Immokalee. It would give them an understanding of what it is like to work in a diverse, lowincome school environment. Some of these pre-service teachers may value their experience and make a commitment to teach in Immokalee upon completion of their education. Many of the teachers in this study did not directly pursue a teaching job in Immokalee, but have remained in Immokalee because they are satisfied with their position. Also, candidates who have decided to become teachers later in life should not be eliminated from the application file. Deciding to become a teacher early in life seems to have no bearing on a teacher's likelihood of remaining in Immokalee. 


\section{TEACHER RETENTION IN A LOW-INCOME DIVERSE COMMUNITY}

\section{Hire Individuals Who are Familiar with the School Context}

All, but one of the teachers in this study could relate to their students' circumstances in some way. Most teachers have experienced similar situations to their students and can relate to their challenging situations. When hiring individuals, principals should consider applicants' previous experience. Those teachers who have had a great deal of experience in low-income, diverse schools and individuals who express the ability to relate to their students' circumstances would be ideal candidates. For those teachers hired who lack experience in this school context and have not had similar experiences, the district should provide them with materials and information to help them better understand the Immokalee population. One suggestion would be to give each new teacher in Immokalee a copy of Carlene Thissen's (2002) novel, Fields of Hope. This book gives a thorough description of the community's history, culture, and the struggles that many families living in Immokalee deal with every day. Guiding teachers around Immokalee and giving them opportunities to participate in community events would be a positive way to allow teachers to experience the culture first hand and become more comfortable among the population. The community of Immokalee should encourage individuals to pursue a degree in education. Two of the teachers in this study are from Immokalee and expressed their unique ability to understand their students' circumstances and also find great satisfaction being a role model of a person from Immokalee who has been successful in school, despite the challenges. Both of these teachers expressed the need for more teachers who have been born and raised in Immokalee.

\section{Hire Individuals Who are Willing to Differentiate for the Needs of Individual Students}

Principals must hire individuals who are genuinely interested in individual students' success and want to see each child succeed. The teachers in this study view their students as 


\section{TEACHER RETENTION IN A LOW-INCOME DIVERSE COMMUNITY}

individuals, recognize that all students are different, and set reasonable goals for their students. These teachers differentiate their instruction on a regular basis. The students in Immokalee are at various academic levels as well as English ability levels, so successful teachers must be willing to adapt their instruction to meet the needs of these students. Asking questions in the interviews regarding these teachers' prior experience with differentiation would be valuable in addition to asking questions that reveal the candidates willingness to be flexible and to make accommodations for students when necessary. When beginning employment in an Immokalee school and throughout their employment in Immokalee, teachers should be provided with training opportunities, tools, and resources to support them in their effort to differentiate instruction.

\section{Recommendations Regarding Retention}

In order to increase teacher retention in Immokalee, administrators must establish a positive working environment for teachers. Based upon the findings of this study, the researcher makes the following recommendations: First, school personnel must work together to maintain the sense of camaraderie already present in the Immokalee schools. Second, schools must make an effort to improve communication between parents and teachers. Third, the school district must take the steps necessary to improve the community's perception of the schools in Immokalee, and last it is imperative that principals recognize students and teachers' accomplishments on a regular basis.

\section{Maintain Camaraderie}

The schools in Immokalee have successfully established a strong sense of camaraderie. All the teachers spoke about the strong relationships and friendships they have forged at school with co-workers. Staff willingly help each other. It is vital that the schools in Immokalee 


\section{TEACHER RETENTION IN A LOW-INCOME DIVERSE COMMUNITY}

maintain this sense of camaraderie. Since the government continues to impose additional mandates, especially for Title I schools, it is even more important that teachers, administrators, and other school personnel collaborate together and support each other. The results of this study indicate that communication and collaboration seem to be especially prevalent within teams of teachers. Several teachers spoke about going to their team for suggestions and help. Principals should place teachers in teams according to their job description so that teachers can meet together to discuss difficulties and strategies. Also, administrators should create even more opportunities for staff to get to know each other and build supportive relationships.

Administrators should establish an open-door policy in which teachers can ask questions and raise concerns whenever necessary. Teachers need to feel comfortable asking for help. Novice teachers especially, need to feel that they can approach the administration when they need assistance. This sense of camaraderie should extend beyond the school building to the parents and community of Immokalee.

\section{Improve Communication Between Parents and Teachers}

One of the commonly held sources of dissatisfaction for Immokalee teachers is the lack of parent support due to parents' limited education and English language skills. While teachers expressed that parents have a desire to support their child's education, often their circumstances prevent them from doing so. Not only do parents not have the education and English skills necessary to help their child with school work, many migrant students' parents lack understanding of the American school system (BOCES Geneseo Migrant Center, n.d.). They themselves did not attend school in the United States and therefore the expectations they hold for their child may not coincide with the expectations of their child's school. Due to this, the school district should do more to equip parents with the information, skills, and resources necessary for 


\section{TEACHER RETENTION IN A LOW-INCOME DIVERSE COMMUNITY}

them to help their child be successful. One way this can be accomplished is by providing continuing education opportunities for parents. The district could conduct classes that address a variety of topics including: the workings of the American school system, technology, and English skills. Schools should offer these classes at a convenient time for parents so they do not have to miss work to attend. These classes would inform parents about issues such as: state standards, testing, graduation requirements, class scheduling, and school discipline. Many parents from Immokalee are uncomfortable approaching school personnel at the school individually. In a classroom environment, among other parents in similar circumstances, it is likely that parents will be more comfortable asking questions. These classes would also strengthen relationships between parents and build a more supportive school environment.

The Collier County School District is a leading school district in technology. The district should more readily use this technology to enhance communication between teachers and parents in Immokalee. The district should provide informational videos about the school system to parents, especially those who have just moved their families to the United States. Each school in Immokalee should regularly update their website with information in Spanish and HaitianCreole.

Schools in Immokalee need to establish an efficient system for contacting parents. Since many teachers employed in Immokalee do not speak Spanish or Haitian-Creole, interpreters are necessary for communication between teachers and parents. Time constraints make communication with parents difficult for teachers in any school setting. Adding additional time to find someone who is available to interpret a conversation makes parent-teacher communication that much more challenging and time consuming. Schools should establish a convenient process that teachers follow when they need to contact an interpreter and schedule a 


\section{TEACHER RETENTION IN A LOW-INCOME DIVERSE COMMUNITY}

time to make a phone call. This would decrease some of the frustrations teachers face when trying to contact a student's parent and allow communication between teachers and parents to occur on a more regular basis.

\section{Create a Positive Perception of Immokalee Schools}

One of the most dissatisfying factors for these teachers was the negative perception held by the community and media. Many of the teachers mentioned the negative reactions they received from others when they informed them that they teach in Immokalee. These negative reactions were even voiced by other employees of the Collier County School system. These comments do not promote a positive working environment for teachers and may contribute to the retention problem. The district should make an effort to positively promote and recognize the students, staff, and families of the Immokalee schools. The district should praise the teachers, students, and employees of the Immokalee schools regularly among the community and in front of other Collier County school personnel. The media should give Immokalee more positive publicity. The educational channel and the local newspaper would be great avenues from which to spotlight the Immokalee schools. District administrators should support schools in Immokalee by making regular visits to classrooms in Immokalee. At district trainings it would be beneficial to allow Immokalee teachers to share their experiences and expertise among fellow teachers in the district. This would make other teachers aware of the unique setting of Immokalee. It would be valuable to invite teachers from around the district to exchange places with a teacher in Immokalee for a day so that district employees have a more accurate understanding of the Immokalee community. 


\section{TEACHER RETENTION IN A LOW-INCOME DIVERSE COMMUNITY}

\section{Recognize Students and Teachers for Their Accomplishments}

Principals should emphasize the goal of having each individual student make progress. Administrators helping teachers identify even the small accomplishments of their students will motivate teachers and will prevent them from getting discouraged. The administration needs to recognize the achievements of students and teachers even if these achievements are not reflected in test scores. Several teachers in the interviews discussed the frustration of not being recognized or rewarded because their school did not receive an "A". Teachers should be applauded for helping students make even small gains. Also, the district could provide teachers in Immokalee with incentives for improving their students' test scores even if these improvements do not meet the state standard required to receive an "A". One teacher summed up this idea when she said:

I read something years ago about retention and I agreed with it. It said, while more money would help attract and maybe even retain better teachers at your high-needs schools, what matters most is that they feel valued. I read years ago that teachers will be very loyal to their administration and their school if they feel valued. Teachers will drive because they know I'm making a difference in this building, and on top of that I'm valued in this building you know and for me that is it. How do you get teachers to want to teach in Immokalee and to stay in Immokalee? Money? Maybe. Make them feel that they're important, make them feel that what they do is of value.

\section{Suggestions for Further Research}

This study explores the background characteristics and motivations of teachers who have remained in an Immokalee school for long lengths of time. The study reveals characteristics of candidates that are most likely to remain in the low-income, high-diversity community of 


\section{TEACHER RETENTION IN A LOW-INCOME DIVERSE COMMUNITY}

Immokalee. Further research in regards to this topic would provide a more thorough understanding of the characteristics of those teacher who demonstrate a commitment to the community of Immokalee.

While this study seeks to gather information from all the schools in Immokalee, the researcher was unable to acquire participants from all the schools. The majority of the participants in this study were teachers from the elementary level. Further research that includes teachers from the middle and high school level would provide more thorough information. A larger sample size would undoubtedly provide more insight.

This study found a strong sense of camaraderie among the teachers and staff in the Immokalee schools. It would be valuable to conduct a study to determine what contributes to this camaraderie. Perhaps the challenges of working in an environment such as Immokalee lends itself to a more collaborative approach, or it may be that carpooling helps build positive relationships among the staff. Further research in regards to this could be conducted to determine what contributes to this sense of camaraderie that is often lacking on other school settings.

It would also be valuable to interview former Immokalee teachers who have left their positions in Immokalee. These interviews would reveal more specific information regarding the reasons teachers leave Immokalee. Do they leave primarily for family reasons? Do they leave because they are dissatisfied with their school experience? What are the background characteristics of the teachers that leave? The results of such a study in addition to the present study may prompt administrators to consider making some changes to improve the retention in their building and would provide even further information regarding which candidates to hire to fill vacant teaching positions in the Immokalee schools. 


\section{TEACHER RETENTION IN A LOW-INCOME DIVERSE COMMUNITY}

\section{Christian Worldview Integration}

The most important task for the Christian is to share the gospel with the unbelieving

world. God expects Christians to share the gospel with people of all nations, tribes, and tongues. There is nothing more important than communicating to others their need of a savior. In Romans 3:23 The Bible (NIV) says, "All have sinned and fall short of the glory of God." The consequences of mankind's sin is death and eternity separated from God in hell. Romans 6:23 states, "For the wages of sin is death." Yet, there is hope for the world because John 3:16 says, "For God so loved the world that he gave his one and only son that whoever believes in him shall not perish but have eternal life." Jesus Christ, who was fully God and fully man, died on the cross as a substitute for mankind's sin. Through Jesus' death and resurrection one can receive salvation and eternal life. This faith in Jesus Christ not only provides the believer with hope for eternity but also for today. Romans 5:1 says, "Therefore, since we have been justified through faith, we have peace with God through our Lord Jesus Christ." The gospel of Jesus Christ brings people into fellowship with God and restores peace in their hearts. This is the message that God commands Christians to proclaim to the ends of the earth. Christians should do everything to glorify God. Colossians 3:17 says, "And whatever you do, whether in word or deed, do it all in the name of the Lord Jesus, giving thanks to God the Father through him." Similarly Colossians 3:23 says, "Whatever you do, work at it with all your heart, as working for the Lord, not for human masters." Christian educators should use teaching as a platform to lead others to Christ. Jesus' last words on earth were, "Therefore go and make disciples of all nations, baptizing them in the name of the Father and of the Son and of the Holy Spirit, and teaching them to obey everything I have commanded you. And surely I am with you always, to the very end of the age" (Matthew 28:19-20). In this scripture God commands Christians to reach out to all people 


\section{TEACHER RETENTION IN A LOW-INCOME DIVERSE COMMUNITY}

groups. God loves all people and everyone is included in God's redemptive plan of salvation regardless of age, education, ethnicity, and socioeconomic status.

America is becoming more diversified than ever before. For the Christian this should be an exciting time. People from all across the world are living in American neighborhoods, working in American workplaces, and their children are attending American schools. Almost all of the people groups can be found within the borders of the United States, and there has never been a time in history when it has been so easy to reach all people for Christ. For this reason, the low retention rate among the nation's most diverse and needy schools should concern Christian educators. This study reveals that many people will not spend time in a community like Immokalee because they are fearful and uncomfortable in such a setting. This should not be the case for the Christian. Christ spent much of his time crossing racial and economic boundaries to reach the world. One prime example is when Jesus spoke to the women at the well. John 4:9 says, "The Samaritan woman said to him, 'You are a Jew and I am a Samaritan woman. How can you ask me for a drink?' (For Jews do not associate with Samaritans).” Jews and Samaritans were not to associate with one another, yet Jesus was bold and crossed this racial boundary. The woman Jesus spoke to was greatly involved in sin and yet he chose to reach out to her even though it was culturally unacceptable. Jesus was not interested in the barriers the culture had created. Rather, he saw that this Samaritan woman needed salvation, and as a result this woman came to know Christ and led others to Christ as well (John 4:42). The Bible says, "For there is no difference between Jew and Gentile-the same Lord is Lord of all and richly blesses all who call on him" (Romans 10:12). Romans 10:14 says: 


\section{TEACHER RETENTION IN A LOW-INCOME DIVERSE COMMUNITY}

How, then, can they call on the one they have not believed in? And how can they believe in the one of whom they have not heard? And how can they hear without someone preaching to them? And how can anyone preach unless they are sent?

While not everyone can or should teach in a setting such as Immokalee, Christians should prayerfully consider working in such a setting and should support and encourage those who do. Settings such as Immokalee provide the Christian with an unprecedented opportunity to reach other nations right here within the borders of the United States. One day all Christians will enter eternity with Christ. At that time, all that will remain is the treasures Christians have "stored up in heaven" (Matthew 6:20). In heaven people from all racial groups, socioeconomic conditions, and languages will live together and serve God. Revelation 7:9-10 says:

After this I looked, and there before me was a great multitude that no one could count, from every nation, tribe, people and language, standing before the throne and before the Lamb. They were wearing white robes and were holding palm branches in their hands. And they cried out in a loud voice: "Salvation belongs to our God, who sits on the throne, and to the Lamb."

American Christians should view the Immokalee community as a mission field. Though the culture and language may be different, their need of a savior remains the same. The Christian that does choose to teach in Immokalee should do so to honor God, not to receive recognition from men. Although people always appreciate recognition, it should not be the Christian's aim. The Christian who serves God fully in the place God has put them receives far greater than man's praise or financial compensation. One receives eternal blessings "where moth and vermin do not destroy" (Matthew 6:20). It should be the Christian's joy to serve God in the 


\section{TEACHER RETENTION IN A LOW-INCOME DIVERSE COMMUNITY}

Immokalee community if God has placed that call on their heart or to support those who do through giving, encouragement, and prayer.

The children attending the Immokalee schools face many challenges and need to see God's love. Christian teachers that serve in Immokalee have the incredible opportunity to demonstrate Christ's love by displaying the fruits of the spirit each and every day in front of their students. Galatians 5:22-23 says, "But the fruit of the Spirit is love, joy, peace, forbearance, kindness, goodness, faithfulness, gentleness, and self-control.” By demonstrating these Godly characteristics to the children in Immokalee, teachers can greatly impact the lives of the next generation and perhaps even lead some to saving faith in Jesus Christ. 
TEACHER RETENTION IN A LOW-INCOME DIVERSE COMMUNITY

\section{References}

Barnes, G., Crowe, E., \& Schaefer, B. (2007). The cost of teacher turnover in five school districts: A pilot study. Retrieved from National Commission on Teaching \& America's Future website: http://nctaf.org/wp-content/uploads/2012/01/NCTAF-Cost-of-TeacherTurnover-2007-full-report.pdf

Bifulco, R., \& Ladd, H.F. (2007). School choice, racial segregation, and test-score gaps: Evidence from North Carolina's charter school program. Journal of Policy Analysis and Management, 26(1), 31-56. doi:10.1002/pam.20226

Bobek, B. L. (2002). Teacher resiliency: A key to career longevity. Clearing House, 75, 202205. doi:10.1080/00098650209604932

BOCES Geneseo Migrant Center (n.d.). Migrant farm workers in the United States [Fact sheet]. Retrieved http://www.unctv.org/content/sites/default/files/0000011508farmworkerfacts.pdf

Boyd, D., Lankford, H., Loeb, S., \& Wyckoff, J. (2005). The draw of home: How teachers' preferences for proximity disadvantage urban schools. Journal of Policy Analysis \& Management, 24(1), 113-132. doi:10.1002/pam.20072

Burney, V. H., \& Beilke, J. R. (2008). The constraints of poverty on high achievement. Journal for the Education of the Gifted, 31(3), 171-197. Retrieved from http://jeg.sagepub.com

Byrne, B. M. (1994). Burnout: Testing for the validity, replication, and invariance of causal structure across elementary, intermediate, and secondary teachers. American Educational Research Journal, 31(3), 645-673. doi:10.3102/00028312031003645 


\section{TEACHER RETENTION IN A LOW-INCOME DIVERSE COMMUNITY}

Callet, V. J. (2005). Test review: High-stakes testing: Does the California high school exit exam measure up? Language Assessment Quarterly, 2(4), 289-307. doi:10.1207/s15434311laq0204_3

Clayton, J. K. (2011). Changing diversity in U.S. schools: The impact on elementary student performance and achievement. Education \& Urban Society, 43(6), 671-695. doi:10.1177/0013124510380909

Clotfelter, C. T., Ladd, H. F., \& Vigdor, J. L. (2006). Teacher-student matching and the assessment of teacher effectiveness. Journal of Human Resources, 41(4), 778-820. doi:10.3368/jhr.XLI.4.778

Clotfelter, C. T., Ladd, H. F., \& Vigdor, J. L. (2010). Teacher credentials and student achievement in high school: A cross-subject analysis with student fixed effects. Journal of Human Resources, 45(3), 655-681. Retrieved from http://uwpress.wisc.edu/journals/journals/jhr.html

Cockburn, A. D. (2000). Elementary teachers' needs: Issues of retention and recruitment. Teaching and Teacher Education, 16(2), 223-238. http://dx.doi.org/10.1016/S0742051X(99)00056-6

Codd, J. (2005). Teachers as 'managed professionals' in the global education industry: The New Zealand experience. Educational Review, 57(2), 193-206. doi:10.1080/0013191042000308369

Cohen, R. M. (2009). What it takes to stick it out: Two veteran inner-city teachers after 25 years. Teachers \& Teaching, 15(4), 471-491. doi:10.1080/13540600903057252

Collier County Public Schools. (2012). District Profile [Fact Sheet]. Retrieved from http://www.collierschools.com/about/fastfacts.asp 


\section{TEACHER RETENTION IN A LOW-INCOME DIVERSE COMMUNITY}

Darling-Hammond, L. (2003). Keeping good teachers: Why it matters, what leaders can do. Educational Leadership, 60(8), 6-13. Retrieved from http://www.ascd.org/publications/educational-leadership.aspx

Darling-Hammond, L. (2007, May 21). Evaluating No Child Left Behind. The Nation, 11-18. Retrieved from http://www.thenation.com

Darling-Hammond, L. (1997). Doing what matters most: Investing in quality teaching. New York, NY: National Commission on Teaching \& America's Future.

Day, C., \& Gu, Q. (2009). Veteran teachers: Commitment, resilience and quality retention. Teachers \& Teaching, 15(4), 441-457. doi:10.1080/13540600903057211

Demerouti, E., Bakker, A. B., Nachreiner, F., \& Schaufeli, W. B. (2001). The job demandsresources model of burnout. Journal of Applied Psychology, 86(3), 499-512. doi:10.1037/0021-9010.86.3.499

Dinham, S. (1992, July). Human Perspectives on Teacher Resignation: Preliminary Results of One Investigation. Paper presented at the Annual Meeting of the Australian Council for Educational Administration, Darwin, Northern Territory, Australia. Retrieved from ERIC database. (ED350713)

Dinham, S., \& Scott, S. (2000). Moving into the third, outer domain of teacher satisfaction. Journal of Educational Administration, 38(4), 379-396. doi:10.1108/09578230010373633

Donaldson, M. L., \& Johnson, S. M. (2011). Teach for America teachers: How long do they teach? Why do they leave? Phi Delta Kappan, 93(2), 47-51. Retrieved from http://intl.kappanmagazine.org 


\section{TEACHER RETENTION IN A LOW-INCOME DIVERSE COMMUNITY}

Elfers, A. M., Plecki, M. L., \& Knapp, M. S. (2006). Teacher mobility: Looking more closely at "the movers" within a state system. Peabody Journal of Education, 81(3), 94-127. doi:10.1207/S15327930pje8103_4

Fairchild, S., Tobias, R., Corcoran, S., Djukic, M., Kovner, C., \& Noguera, P. (2012). White and black teachers' job satisfaction: Does relational demography matter? Urban Education, 47(1), 170-197. doi:0.1177/0042085911429582

Falch, T., \& Rønning, M. (2007). The influence of student achievement on teacher turnover. Education Economics, 15(2), 177-202. doi:10.1080/09645290701263104

Ferguson, R. F. (2007). Become more sophisticated about diversity. Journal of Staff Development, 28(3), 33-34. Retrieved from http://learningforward.org/publications/jsd

Florida Department of Education (n.d.). Exceptional Student Education (ESE). Retrieved from http://www.fldoe.org/ese/ese-home.asp.

Friedman, I. A. (1995). Student behavior patterns contributing to teacher burnout. Journal of Educational Research, 88(5), 281-89. doi:10.1080/00220671.1995.9941312

Ganchorre, A., \& Tomanek, D. (2012). Commitment to teach in under-resourced schools: Prospective science and mathematics teachers' dispositions. Journal of Science Teacher Education, 23(1), 87-110. doi:10.1007/s10972-011-9263-y

Gehrke, R. S., \& McCoy, K. (2007). Considering the context: Differences between the environments of beginning special educators who stay and those who leave. Rural Special Education Quarterly, 26(3), 32-40. Retrieved from http://acres-sped.org/journal

Glaser B. \& Strauss A.L. (1967) The Discovery of Grounded Theory: Strategies for Qualitative Research. Aldine Publishing Company, New York. 


\section{TEACHER RETENTION IN A LOW-INCOME DIVERSE COMMUNITY}

Goldhaber, D., Gross, B., \& Player, D. (2011). Teacher career paths, teacher quality, and persistence in the classroom: Are public schools keeping their best? Journal of Policy Analysis and Management, 30(1), 57-87. doi:10.1002/pam.20549

Guin, K. (2004). Chronic teacher turnover in urban elementary schools. Education Policy Analysis Archives, 12(42), 1-30. Retrieved from http://epaa.asu.edu

Haberman, M. (1995). Selecting `star' teachers for children and youth in urban poverty. Phi Delta Kappan, 76(1), 777-781. doi:10.2307/20405456

Hughes, J., \& Manuel, J. (2006). ‘It has always been my dream’: Exploring pre - service teachers' motivations for choosing to teach. Teacher Development, 10(1), 5-24. doi:10.1080/13664530600587311

Humes, K. R., Jones N. A., Ramirez, R. R. (2010). Overview of race and Hispanic origin: 2010 (C2010BR-02). Retrieved from the U.S. Census Bureau website: http://www.census.gov/prod/cen2010/briefs/c2010br-02.pdf

Ingersoll, R. M. (2001). Teacher turnover and teacher shortages: An organizational analysis. American Educational Research Journal, 38(3), 499-534. doi:10.3102/00028312038003499

Inman, D., \& Marlow, L. (2004). Teacher retention: Why do beginning teachers remain in the profession? Education, 124(4), 605-614. Retrieved from http://www.projectinnovation.biz/education_2006.html

Johnson, L. (2011). Targeted comprehensive induction for urban educators: An exploration of teacher motivation and retention. New Educator, 7(2), 131-152.

doi:10.1080/1547688X.2011.574586 


\section{TEACHER RETENTION IN A LOW-INCOME DIVERSE COMMUNITY}

Johnson, R. B., \& Christensen, L. B. (2008). Educational research: Quantitative, qualitative, and mixed approaches (3rd ed.). Thousand Oaks, CA: Sage.

Leech, N. L., \& Onwuegbuzie, A. J. (2007). An array of qualitative data analysis tools: A call for data analysis triangulation. School Psychology Quarterly, 22(4), 557-584. doi:10.1037/1045-3830.22.4.557

Littrell, P. C., \& Billingsley, B. S. (1994). The effects of principal support on special and general educators' stress, job satisfaction, school commitment, health, and intent to stay in teaching. Remedial \& Special Education, 15(5), 297-310. doi:10.1177/074193259401500505

McKinney, S. E., Berry, R. Q., Dickerson, D. L., \& Campbell-Whately, G. (2007). Addressing urban high-poverty school teacher retention: Why effective teachers persevere. Educational Research and Review, 3(1), 1-9. Retrieved from http://www.academicjournals.org/err/index.htm

Monk, D. H. (2007). Recruiting and retaining high-quality teachers in rural areas. Future of Children, 17(1), 155-174. doi:10.1353/foc.2007.0009

Moriarty, V., Edmonds, S., Blatchford, P., \& Martin, C. (2001). Teaching young children: Perceived satisfaction and stress. Educational Research, 43(1), 33-46. doi:10.1080/00131880010021276

Murnane, R. J., \& Olsen, R. J. (1989). The effects of salaries and opportunity costs on duration in teaching: Evidence from Michigan. Review of Economics \& Statistics, 71(2), 347-352. Retrieved from http://www.mitpressjournals.org/loi/rest

Muyskens, P., Betts, J., Lau, M. Y., \& Marston, D. (2009). Predictive validity of curriculumbased measures in the reading assessment of students who are English language learners. 


\section{TEACHER RETENTION IN A LOW-INCOME DIVERSE COMMUNITY}

California School Psychologist, 14, 11-21. Retrieved from

http://www.education.ucsb.edu/school-psychology/CSP-Journal/

Omenn Strunk, K., \& Robinson, J. P. (2006). Oh, won't you stay: A multilevel analysis of the difficulties in retaining qualified teachers. Peabody Journal of Education, 81(4), 65-94. doi:10.1207/s15327930pje8104_4

Organisation for Economic Cooperation, and Development. (2011). Building a high-quality teaching profession: Lessons from around the world. Paris, France: OECD Publishing.

Perie, M., Baker, D. P. (1997). Job satisfaction among America's teachers: Effects of workplace conditions, background characteristics, and teacher compensation (NCES-97-471). Retrieved from National Center for Education Statistics website: http://nces.ed.gov/pubs97/97471.pdf

Prewitt-Diaz, J. O., Trotter, R.T. \& Rivera, V.A. (1990). The effects of migration on children: An ethnographic study. State College, PA: Center de Estudios Sobre la Migración [Center for the Study of Migration].

Renzulli, L. A., Parrott, H. M., \& Beattie, I. R. (2011). Racial mismatch and school type: Teacher satisfaction and retention in charter and traditional public schools. Sociology of Education, 84(1), 23-48. doi:10.1177/0038040710392720

Richardson, B. K., Alexander, A., \& Castleberry, T. (2008). Examining teacher turnover in lowperforming, multi-cultural schools: Relationships among emotional labor, communication symmetry, and intent to leave. Communication Research Reports, 25(1), 10-22. doi:10.1080/08824090701831743 


\section{TEACHER RETENTION IN A LOW-INCOME DIVERSE COMMUNITY}

Rockoff, J. E. (2004). The impact of individual teachers on student achievement: Evidence from panel data. The American Economic Review, 94(2), 247-252.

doi: $10.1257 / 0002828041302244$

Sohoni, D., \& Saporito, S. (2009). Mapping school segregation: Using GIS to explore racial segregation between schools and their corresponding attendance areas. American Journal of Education, 115(4), 569-600. Retrieved from http://www.press.uchicago.edu/ucp/journals/journal/aje.html

Stanford, B. H. (2001). Reflections of resilient, persevering urban teachers. Teacher Education Quarterly, 28(3), 75-87. Retrieved from http://www.teqjournal.org

Stinebrickner, T. R. (1998). An empirical investigation of teacher attrition. Economics of Education Review, 17(2), 127-36. http:://dx.doi.org/10.1016/S0272-7757(97)00023-X

Stuit, D. A., \& Smith, T. M. (2012). Explaining the gap in charter and traditional public school teacher turnover rates. Economics of Education Review, 31(2), 268-279. http://dx.doi.org/10.1016/j.econedurev.2011.09.007

Thissen, C.A. (2002). Immokalee’s fields of hope. Lincoln, NE: iUniverse Star.

U.S. Census Bureau. (2010). State \& county quickfacts: Immokalee CDP, Florida. [Fact sheet] Retrieved from http://quickfacts.census.gov/qfd/states/12/1233250.html

U.S. Department of Education. (2004). Guide to education and No Child Left Behind. Retrieved from http://www.ed.gov/print/nclb/overview/intro/guide/guide.html

U.S. Department of Health \& Human Services. (2009). Civil Rights. Retrieved from http://www.hhs.gov/ocr/civilrights/resources/specialtopics/lep/ 


\section{TEACHER RETENTION IN A LOW-INCOME DIVERSE COMMUNITY}

Velasquez, L. C. (1994). Migrant \& seasonal farmworkers: An invisible population. In J. P.

Hautecouer (Ed.), Alpha 94: Literacy and cultural development strategies in rural areas.

Retrieved from http://www.eric.ed.gov/PDFS/ED386355.pdf

Xin, M., \& MacMillan, R. B. (1999). Influences of workplace conditions on teachers' job satisfaction. Journal Of Educational Research, 93(1), 39-47.

doi:10.1080/00220679909597627 
TEACHER RETENTION IN A LOW-INCOME DIVERSE COMMUNITY

Appendix

\section{Interview Questions}

1. What type of teaching license do you have (subject, state, temporary, professional etc.)

2. Are you a national board certified teacher?

3. What is the highest level of education you have completed?

4. What degree(s) have you earned?

5. What college(s) did you attend?

6. Did you go back for your degree after beginning teaching or before? If you completed your masters, did you earn that while you were teaching?

7. Do you have any other academic credentials that I should know about?

8. Are you married?

9. Do you have children?

10. Do you speak another language?

11. Do you live in Immokalee? If not, where do you live and how long is your commute?

12. Do you carpool?

13. How many years of teaching experience do you have?

14. Please explain your prior work experience. Describe the position(s) you held, where you worked, and for how long. Please go in chronological order and include any positions you held outside the realm of education.

15. Do you have any personal faith?

16. If so, how does this impact/effect your job?

17. What outside activities are you involved in?

18. Where did you grow up? 
TEACHER RETENTION IN A LOW-INCOME DIVERSE COMMUNITY

19. Describe the elementary, middle, and high school you attended. Were they public, private, or charter schools? Explain the demographics of these schools.

20. Did you like school as a child? Was school a positive experience for you?

21. Was school easy for you or did you find it challenging?

22. Where did you attend college?

23. Describe the teacher training you experienced at your college.

24. During your teacher training, did you get much experience in low-income high diversity schools?

25. What was your student teaching experience like?

26. When did you decide you wanted to be a teacher?

27. What was your reason for wanting to enter the teaching profession?

28. What are your professional goals?

29. When you first considered teaching, what school setting did you foresee yourself teaching in?

30. Describe the process and events that occurred that resulted in your decision to teach in Immokalee.

31. How long have you taught at this school?

32. When you began teaching here did you have a mentor? Was this a positive experience? Do you think it helped you?

33. Do you have a mentor now?

34. Do you believe you make a difference in children's' lives? If so, in what way?

35. Do you have a teacher that you look up to or aspire to be like? If so, describe that teacher.

36. Describe your teaching philosophy.

37. Describe your teaching style.

38. Describe a successful day at school. 
TEACHER RETENTION IN A LOW-INCOME DIVERSE COMMUNITY

39. What do you enjoy most about teaching in Immokalee?

40. What do you find the most rewarding?

41. What do you think is the most challenging about teaching in Immokalee?

42. How do you deal with these challenges?

43. Do you feel that you are primarily responsible for the academic achievement of your students?

44. How do you deal with bureaucracies?

45. Do you feel like there are people within your school that you can go to for support? If so, how often do you request support or help from them?

46. Do you work together with other teachers often?

47. Are you friends with people at work? Do you do things outside of school?

48. Are you involved in many activities outside of school? If so, what types of activities?

49. How do you balance work and your home life?

50. How do others feel about your decision to teach in Immokalee?

51. Why motivates you to continue teaching in Immokalee?

52. Do you have any additional responsibilities in the school (i.e. team leader etc.)

53. Do you feel like you can relate to your students' life circumstances? If so, in what way?

54. What do you find the most stressful about your job?

55. Do you have people outside of school that you can go to for support? If so, who provides this support? 